NBER WORKING PAPER SERIES

\title{
ISRAEL'S TRIUMPH OVER INFLATION: THE LONG AND WINDING ROAD
}

\author{
Assaf Razin \\ Working Paper 23061 \\ http://www.nber.org/papers/w23061
NATIONAL BUREAU OF ECONOMIC RESEARCH
1050 Massachusetts Avenue
Cambridge, MA 02138
January 2017

The views expressed herein are those of the author and do not necessarily reflect the views of the National Bureau of Economic Research.

NBER working papers are circulated for discussion and comment purposes. They have not been peer-reviewed or been subject to the review by the NBER Board of Directors that accompanies official NBER publications.

(C) 2017 by Assaf Razin. All rights reserved. Short sections of text, not to exceed two paragraphs, may be quoted without explicit permission provided that full credit, including $\odot$ notice, is given to the source. 
Israel's Triumph over Inflation: The Long and Winding Road

Assaf Razin

NBER Working Paper No. 23061

January 2017

JEL No. E0,F0

\title{
ABSTRACT
}

The paper gives an economic-history perspective of the long struggle with inflation. It covers the early acceleration to three-digit levels, lasting 8 years; The stabilization program, based on political backing triggered sharp fall in inflationary expectation, and consequently to sharp inflation reduction to two-digit levels; The convergence to the advanced countries' levels during the "great Moderation"; and Israel's resistance to the deflation-depression forces that the 2008 crisis created. The emphasis is on the forces of globalization and the building of institutions, political, regulatory, financial, budget design, and monetary, which helped stabilize prices and output.

\author{
Assaf Razin \\ Eitan Berglas School of Economics \\ Tel Aviv University \\ Tel Aviv 69978 \\ ISRAEL \\ and Cornell University and CEPR \\ and also NBER \\ ar256@cornell.edu
}


Globalization, the integration of markets in goods, services and capital, whose pace accelerated in the 1990s with the fall of communism, is currently under attack. Globalization and new-technology forces accelerated the decline in low-tech manufacturing industries, the rise of the financial and the surge of immigration. Brexit may have been the first wave of anti-globalization and rising populism that gushes over most advanced nations. Then came the 2017 change of guards in the US. Meanwhile, European countries, straightjacketed inside the confines of the single currency area like Germany, France, Greece, the Netherland, Spain, Poland and others, witness the anti-EU forces gather strength. Israel in many ways provides a counter example. Globalization-technology forces, like the technology surge, the new markets in East Asia, and immigration waves, have been a boon. Israel's remarkable developments provides an historical counter example. ${ }^{1}$

\footnotetext{
${ }^{1}$ Israel fast development although unique, is not unknown elsewhere. Ireland somewhat parallels Israel in awesomely benefitting from globalization. Ireland entered the 1950 s as a very poor post-colonial society. However, it realized major successes by the integration into the EU, and reaching an elite hi-tech status. Ireland, was able to attract from the rest of the world (other than the EU) massive FDI, thanks to its being a tax-sheltered gate to the EU massive markets. Ireland however poorly regulated its banking sector and allowed the credit bubble to flourish in the wake of the 2008-global-financial crash. It's over exposed banking sector collapsed during the financial crisis. Ireland has continued to be burdened by the Eurozone's nearly secular stagnation. ${ }^{1}$ Israel robust performance during the crisis is partly attributable to not being a member of a single currency area.
} 
Israel has had a remarkable development, emerging from a low-income high-inflation developing economy in the 1970s, to a medium to high income advanced economy in the 2000s; at all stages of its development globalization played a key role.

\section{The Inflation Crisis}

Israel's Inflation accelerated in the 1970s, rising steadily from $13 \%$ in 1971 to $111 \%$ in 1979. Some of this higher inflation was "imported" from the world economy, instigated by extreme oil price rises in 1973 and 1979. Inflation kept gathering pace. From 133\% in 1980, it leaped to 191\% in 1983 and then to $445 \%$ in 1984 , threatening to become a four-digit figure within a year or two. After several failed efforts, the successful phase of the stabilization of the Israeli economy began with the heterodox program introduced in July 1985. The initial success of the stabilization program included a decrease in inflation, from 445 percent in 1984 to 185 percent in 1985 and 20 percent in 1986. There was also an increase in real economic activity, with the annual growth in business sector product per capita rising from 0.4 percent in 1984 to 4.3 percent in 1985 and 3.6 percent in 1986. However, in the second half of 1987, the economy slid into recession, an aftershock event. Inflation however did not converge to advanced countries' inflation. ${ }^{2}$

Figure 1.1 describes the price level and the exchange rate paths for the inflation-rising period in the wake of the hyperinflation crisis, and the aftermath of the 1985 stabilization program.

\footnotetext{
${ }^{2}$ Calvo and Vegh (2001) observe that in many high-inflation stabilization programs around the world inflation failed to converge to world averages. Real economic activity expanded in the early years of the stabilization program. Later in the program, a recession set in. Unlike Israel stabilization program, in many developing economies the program later collapsed.
} 


\section{Figure 1.1: Price Level and Exchange Rate, 1977-1986}

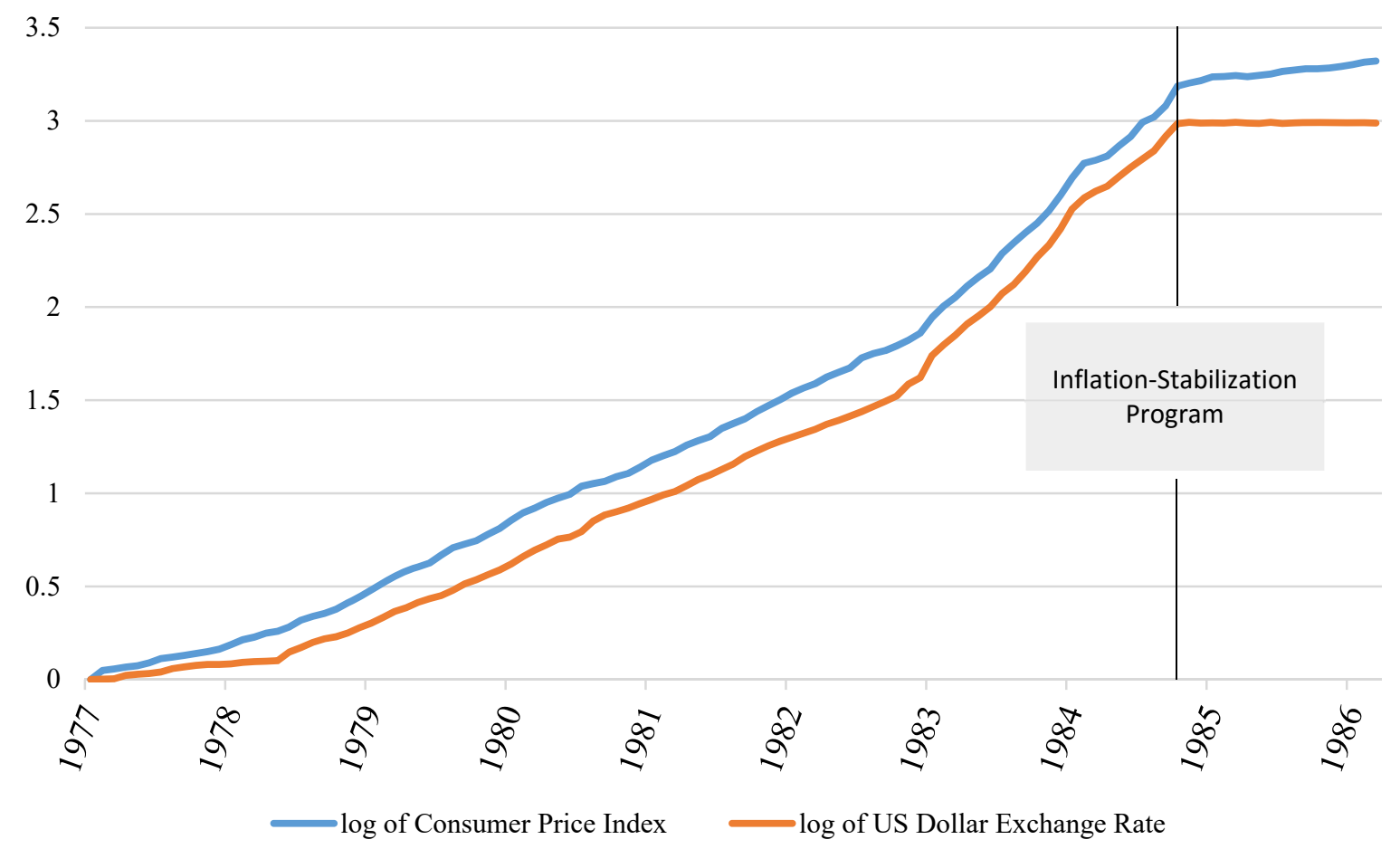

Source: Bank of Israel

The figure demonstrates the accelerated path of inflation, and the lagging path of exchange-rate depreciations in the 1980s. It highlights the sharp flattening of inflation that took place immediately after the implementation of the 1985 stabilization-policy package. All along, the depreciations fell short of inflation; therefore, the real exchange has been markedly appreciated throughout the period. The real-exchange-rate appreciation naturally corresponds also to the rise in unemployment, and output growth decline. Figure 1.2 describes the path of major output-andemployment indicators. They point out to severe slackness in economic activity during the hyperinflation crisis leading to unprecedented unemployment. 


\section{Figure 1.2: Output Growth and Unemployment, 1977-1986}

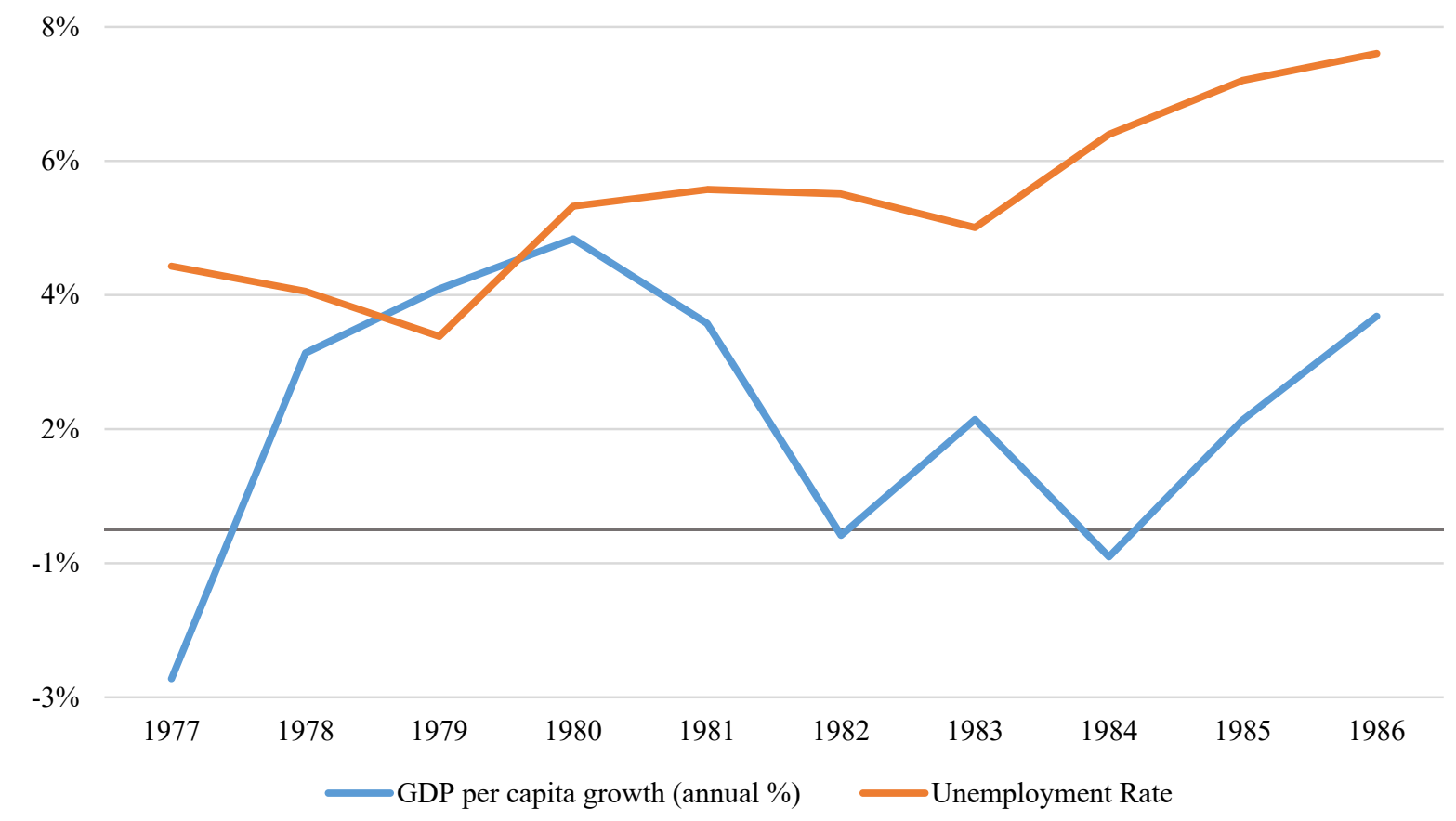

Source: Israel CBS, World Bank

Economic activity was impacted severely by the swelling credit frictions. Because the inflation crisis undermined the well functioning of credit institutions. Banks and financial market regulation also failed during the 1980s. At the time, bank stocks accounted for more than $90 \%$ of all issued stocks in the stock market. Their monopoly power in the stock market allowed the large banks to build up low-cost loan portfolio, and give it out to borrowers with poor selection, and poor monitoring. Central bank oversight of commercial banks was almost non-existent. Israel's Securities and Exchange Commission was powerless, legally and administratively. Massive stock issues allowed banks to increase their available capital as a source of investments, loans, etc. To get market participants to continue investing in the large bank's stock, it began buying back its 
own stock. On October 6, 1983, known as the "Black Thursday", an onslaught of banks' stock sales brought down the stock market. Largest banks became state-owned through a swift bailout.

\subsection{Economic-Regime Switch}

The economic crisis started to develop when the opposition "Gahal" (now "Likkud") party gained power for the first time since independence. The political upheaval in 1977, the socalled "Maapach", was a game changer for economic policy in Israel. The newly elected government abruptly switched away from a long-running economic regime, which had been able to maintain fiscal discipline in the presence of strong external shocks (the Yom Kippur War and the first Oil Crisis). Monetary policy was moderately accommodative, underpinned by a fixed exchange rate regime; shielded from capital flights by capital controls. Notwithstanding the oil price shock, inflation was low double digit.

A useful way to understand the framework within which the economic policy was conducted prior to the political regime switch, and afterwards, is to think about the basic trilemma in international finance. ${ }^{3}$ In international finance, the tri-lemma stems from the fact that, in almost every country, economic policy makers would like to achieve the following goals: First, make the country's economy open to international capital flows, because by doing so, policy makers of a country enable foreign investors to diversify their portfolios overseas and achieve risk sharing. The country also benefits from the expertise brought to the country by

\footnotetext{
${ }^{3}$ The trilemma as a situation in which someone faces a choice among three options, each of which comes with some inevitable problems. In international finance it is cast in terms of economic regime choices. The international finance trilemma goes back to the classical works of Flemming (1962), and Mundell (1963). See Mankiw for blog interpretation (2010). For a balance of payments crisis model in the trilemma regime-switch framework, see Appendix 1A.
} 
foreign investors. Second, use monetary policy as a tool to help stabilize inflation, output, and the financial sector in the economy. This is achieved as the central bank can increase the money supply, reduce interest rates when the economy is depressed and reduce money growth, and raise interest rates when it is overheated. Moreover, the central bank can serve as a lender of last resort in case of financial panic. Third, maintain stability in the exchange rate. This is because a volatile exchange rate, at times driven by speculation, can be a source of broader financial volatility and makes it harder for households and businesses to trade in the world economy and for investors to be able to plan.

The problem, however, is that a country can only achieve two of these three goals. In order to maintain a fixed exchange rate and capital mobility, the central bank loses its ability to control the interest rate or equivalently the monetary base — its policy instruments — as the interest rate is anchored to the world interest rate by the interest rate parity, and the monetary base is automatically adjusted. This is the case of individual members of the European Monetary Union. In order to keep control over the interest rate or equivalently the money supply, the central bank has to let the exchange rate float freely, as in the case of the United States. If the central bank wishes to maintain both exchange rate stability and control over the monetary policy, the only way to do it is by imposing capital controls, as in the case of China.

Following the 1977 political change the economic regime switched from pegged exchange rate, capital controls and fiscal discipline to loosely managed exchange rate, relaxed controls on outgoing capital flows, and fiscal laxness. Right from the beginning, the new government lifted some capital controls without putting safe guards in place; that is, no prudent financial and banking regulatory measures existed. Intensive shifts in demand and supply for foreign exchange followed almost instantly. Key to the steady increase in inflation, the new populistic government also 
embarked on an uncontrolled path of fiscal expansion accommodated by monetary expansion. Exchange rate and capital flow fluctuations called for the Bank of Israel to intervene occasionally, at first, and significantly later, in the foreign exchange market on a day-to-day basis to smooth out these fluctuations;. A massive wave of capital flight caused over a few years a fast depletion of the stock of international reserves, which weakened the ability of Bank of Israel to intervene in the foreign exchange market. The exchange rate was at a free fall. Following up on the open economy tri-lemma; asserting that a fixed exchange rate regime and perfect capital mobility must erode the ability of the central bank to stabilize employment and price fluctuations. Therefore, Israel lost control over inflation. Lax safeguards brought stock market crashes. The lesson learned from the first-generation currency crisis literature is that such inconsistent set of policies become quickly unsustainable; leading to massive speculative attacks on international reserves, followed rounds of financial and stock market crashes.

\subsection{Political Deadlock Ends}

Following almost 8 years of the hyperinflation economic chaos, the Israeli voters brought about some major political rebalancing towards the political center. The newly established Unity Government (“Likkud” plus “Avoda”) implemented successfully key stabilization measures; all of them required political consensus. ${ }^{4}$ A new legislation ("Khok Hahesderim") allowed the

\footnotetext{
${ }^{4}$ Schneider and Tornell (2004) provide a model of boom-bust episodes in middle-income countries which may explain the logic of the boom-bust episodes which followed the stabilization program. It is based on sectoral differences in corporate finance: the non-tradable sector (e.g., real estate and financial services) is special in that it faces a contract enforceability problem and enjoys bailout guarantees (e.g. bailing out mortgages). As a result, currency mismatch in the balance sheet arise endogenously in that sector. This sectoral asymmetry allows the model to replicate the main features of observed boom-bust episodes. In particular, episodes begin with a lending boom and a real appreciation, peak in a self-fulfilling crisis during which a real depreciation coincides with widespread bankruptcies, and end in a recession and credit crunch. Israel's economy fully recovered in the late 1980s and early 1990s, a time when there was a new wave of immigrants from the former Soviet Union (Chapter 2). For detailed account of the stabilization policy, see Razin and Sadka (1993).
} 
government to exercise tighter control over its spending and taxation. A new law forbade the Central Bank to monetize the budget deficit ("Khok Iee Hadpassa"), and ended the accommodating monetary policy. A Tri-Party agreement between the government, the Federation of Labor ("Histadrut”) and the association of private-sector employers stabilized the wage-price dynamics and enabled a sharp nominal devaluation that ended in a competitiveness-boosting real devaluation. The exchange rate depreciation had not passed through to wages and prices; in high likelihood because the entire macro regime has changed; as in the modern expectations-based macroeconomic setup. Because of the credibility of the policy measures, backed by the Tri-Party agreement between the unified government, the Federation of Labor and the industry employer organization, and the greater independence of the central bank, inflation expectations adjusted rapidly to the policy steps. ${ }^{5}$

\subsection{Inflation and Fiscal Revenues}

Israel's high inflation calamity amounted to a crisis of political and economic institutions. Failing economic governance made it essential for the government to raise revenue through money expansion. At the time when the newly elected government was catering to populistic demands, the printing press was used to finance the fast-expanding government spending and transfers.

Dividends from seigniorage (the profit made by a government by issuing currency) are derived from the exclusive ability of the central bank to issue bank notes. In addition, central bank can hold required reserves from commercial bank deposits, which pay no interest. Central banks can also inflate the non-indexed portion of the public debt and raise the real revenue intake with

\footnotetext{
5 This expectations-changing episode is akin to Volcker-policy effect on inflationary expectations in the US, see Sargent (1999).
} 
progressive tax schedule. However, how much can the central bank lower the consolidatedgovernment fiscal burden depends not just, on how actual inflation is consistent with expected inflation. ${ }^{6}$

The central lesson from the Friedman (1971) is that steady-state seigniorage from revenue maximizing central bank is small. However, Israel, as well as previous historical episodes, offer a counter example. Inflation spikes can be a significant source for government revenue. Time inconsistency on the part of the central bank in producing these spikes are due to harmful incentives. They lead policymakers to implement inflation levels that they may eventually come to regret. These incentives are no rarity; they are very common in economies that do not have the instruments to reach a first-best equilibrium. Moreover, these incentives cannot be ruled out, even under rational expectations in such a time-inconsistent setup. On this issue, Calvo (2016) writes: "Repeated use of surprise inflation is unlikely to be successful in increasing seigniorage, because the public will start to expect a rate of inflation larger than the one that optimizes steady-state revenue from inflation. Thus, eventually the economy may land on the excessive-inflation territory highlighted in Friedman (1971). However, this is not due to an elementary economics error on the side of the central bank, as Friedman's results might lead us to conclude. An inflation spike is, in the short run, one of the cheapest and most expeditious manners for securing additional fiscal revenue. Moreover, this "carrot" is always there. As noted, though, a problem arises if the government repeatedly reaches out for the carrot. However, even in this case, the evidence

\footnotetext{
${ }^{6}$ Indeed, Edi Karni (1983), made rough calculations and found significant seignorage revenue that Israel's hyperinflation generated. In a related context, Cukierman (1998) brings evidence for a significant share of revenue attributable to seigniorage in the 1920s' German hyperinflation.
} 
presented in Friedman (1971) does not prove that authorities were making an error. To assess that, one needs information of how quickly the public catches up with the inflation-spike strategy".

Even in the time inconsistency paradigm ${ }^{7}$, however, there is room for policy. One could try to neutralize the harmful incentives if the central bank banned from extending loans to the fiscal authority. This is why the 1985 Israel inflation stabilization package included the non-printing item, preventing the Bank of Israel to purchase from the treasury directly government treasuries: "Chok Iee Haadpasa".

Sargent (1999) argues that high inflation can be stopped quickly, and at a low cost. His argument is that inflationary expectations are quick to adjust when the economic regime shifts considerably. However, he ignores the fiscal burden and the income distribution that follow.

What are the fiscal implications of deep-rooted inflation expectations, before hyperinflation is stopped?

Imagine a simple economy where there is a stock of public debt denominated in domestic currency, D. ${ }^{8}$ We denote one-period nominal interest rate byi. Then, the next-period full service of the government debt (i.e., principal plus interest) will be $(1+i) D$. We choose the units of measurement so that the present price level is equal to one, and assume that the real interest rate is equal to zero. We also denote the one-period expected inflation rate, $\pi^{e}$, so that inclusive of the inflation premium, the nominal (gross) interest rate is $i=1+\pi^{e}$, and the next-period price level is equal to $1+\pi^{e}$. If the government surprise market participants by setting the actual inflation

\footnotetext{
${ }^{7}$ See Kydland and Prescott (1977) and Calvo (1978).

${ }^{8}$ See Calvo (1992).
} 
rate equal to zero, so that the actual bond-return gross return is equal to one, the actual real burden of servicing the next-period debt is equal to:

$\left(1+\pi^{e}\right) D$

On the other hand, if the government fulfills the private sector entrenched inflationary expectations and set the actual inflation equal to expected inflation, the real burden of the debt is just

$D$.

Thus, the temptation not to stop inflation in its tracks may be irresistible.

Similarly, if the government surprise market participants by abrupt stopping of hyperinflation in the presence of entrenched inflation expectations, the fiscal burden of public sector wage bill and subsidies to basic food must rise. Therefore, the government may hesitate to do so.

To overcome this difficulty there must be a full-fledged social agreement between the government, savers (who hold government bonds), public sector wage earners, and recipients of food subsidies. To fix the inflated outlays on debt service, wage bill, and subsidies, some major redistribution of income must accompany the inflation-halting step. This is in essence the lesson from Israel's inflation stabilization policy. 


\subsection{A Balance of Payments' Crisis}

Inflation crises are often intertwined with balance-of-payment crises. Budget deficits were the root cause of the balance-of-payment- cum - inflation crisis. The high-inflation period (1977-1985) comprised with prolonged balance-of-payments crisis. Large budget deficits make the inflationemployment tradeoff acute, under the regime of pegged exchange rate and liberalized international capital flows; the pre-stabilization regime in Israel. In order to maintain a pegged exchange rate and liberalized capital mobility, the central bank lost its ability to control the interest rate. Both inflation and unemployment ensued. The stabilization package resulted in a regime switch; the government effectively shifted the regime from the first goal of the tri-lemma to the second goal, while being able to sharply reduce budget deficits. Balance-of-payment crises occur when a country lift restrictions on capital mobility (in Israel it begun in 1977) without the consolidation

its fiscal stance and regulatory institutions; especially those overseeing the financial intermediaries. If under these conditions the country is trying also to maintain a fixed exchange rate regime, it then unavoidably faces conflicting policy needs (such as fiscal imbalances, or a fragile financial sector) that need to be resolved by independent monetary policy.

\subsection{Institutional Changes}

Some of the macroeconomic institutional changes, brought about by the inflation stabilization have lasted until these very days. The hyperinflation cum financial collapse episode has not reoccurred. Thanks to more disciplined monetary and fiscal policies, and well-regulated banks, the inflation rate converged to low rates, enjoyed by the advanced economies during the Great Moderation era. 
In contrast, inflation stabilization programs adopted by other developing countries, especially in Latin America, proved not to have similar long-term durability. Argentine's stabilization program, relying on a rigid currency-board setup as its major pillar, was different. A lack of adequate budget discipline and importantly inadequate bank regulations, were some of the major weaknesses of the program. With a sovereign debt crisis and international capital flow reversal, "all hell broke loose". The abruptly collapsed currency board and the run on the banks created a severe liquidity shortage. Sovereign debt default ensued. The world had cut Argentina from the international capital market. More than 10 years later, prices are not stabile. The country was able only recently to have better access to the international capital markets. Chile's stabilization program, however, had long-lasting outcomes, similarly to the Israeli program.

In contrast to the crisis-management experience in Latin America, the Asian crisis has been a game changing event that put the Asian Economies (particularly South Korea and Indonesia) on a durable growth track. To a large measure, the post-crisis Asian financial and monetary institutions restructuring enabled the entire region to escape the 2008 global crisis.

\section{Disinflation and Globalization}

The globalization wave has swept emerging markets in Latin America, European transition economies, East Asian emerging economies, and Israel, over the last decades. The 1992 singlemarket reform in Europe and the formation of the euro zone were watersheds of globalization. Emerging markets, including China and India, likewise became significantly more open. Wynne and Kersting (2007) note that in the 1970s more than three quarters of industrial countries had 
restrictions of some sort on international financial transactions. By the 2000s, none did. Likewise, restrictions on these transactions among emerging markets fell from 78 percent in the 1970s to 58 percent in the 2000s. Israel was exposed intensively in the globalization forces and was able to exploit them to climb down from three-digit inflation rates in the early 1980s, and the double-digit rates in the late 1980s and early 1990s.

Economic integration of the world economy has been reinforced by the transition from communism to capitalism in the former Soviet Union. Spontaneous privatizers, including the military industrial complex (vpk) began mass sales of natural resources abroad. The USSR's entire prolonged war strategic mineral reserves were shipped out of Russia's Far East ports to Asia, contributing to a decade long plunge in natural resources prices, setting in motion a broad drop in energy products' inflation.

The "Great Moderation" refers to the significant in business-cycle volatility starting in the mid1980 s, believed at that time to be permanent, in developed nations in the later part of the twentieth century. Sometime during the mid-1980s major economic variables such as real GDP growth, industrial production, monthly payroll, and the unemployment rate began to decline in volatility. These reductions are primarily due to greater independence of the central banks from political and financial influences which has allowed them to follow macroeconomic stabilization.

Figure 4.1 describes deviations from trend of the unemployment rate and the bond-yield corporatetreasury spread, for the period 1953-2014. The figure highlights the significant reduction in the fluctuations of the unemployment rate and the bond-yield spread between Baa corporation rates and the treasury rate. 
Figure 4.1: HP Filter de-trended unemployment rate and 5-year bond-yield (corporate/treasury) spread, US, 1953-2014

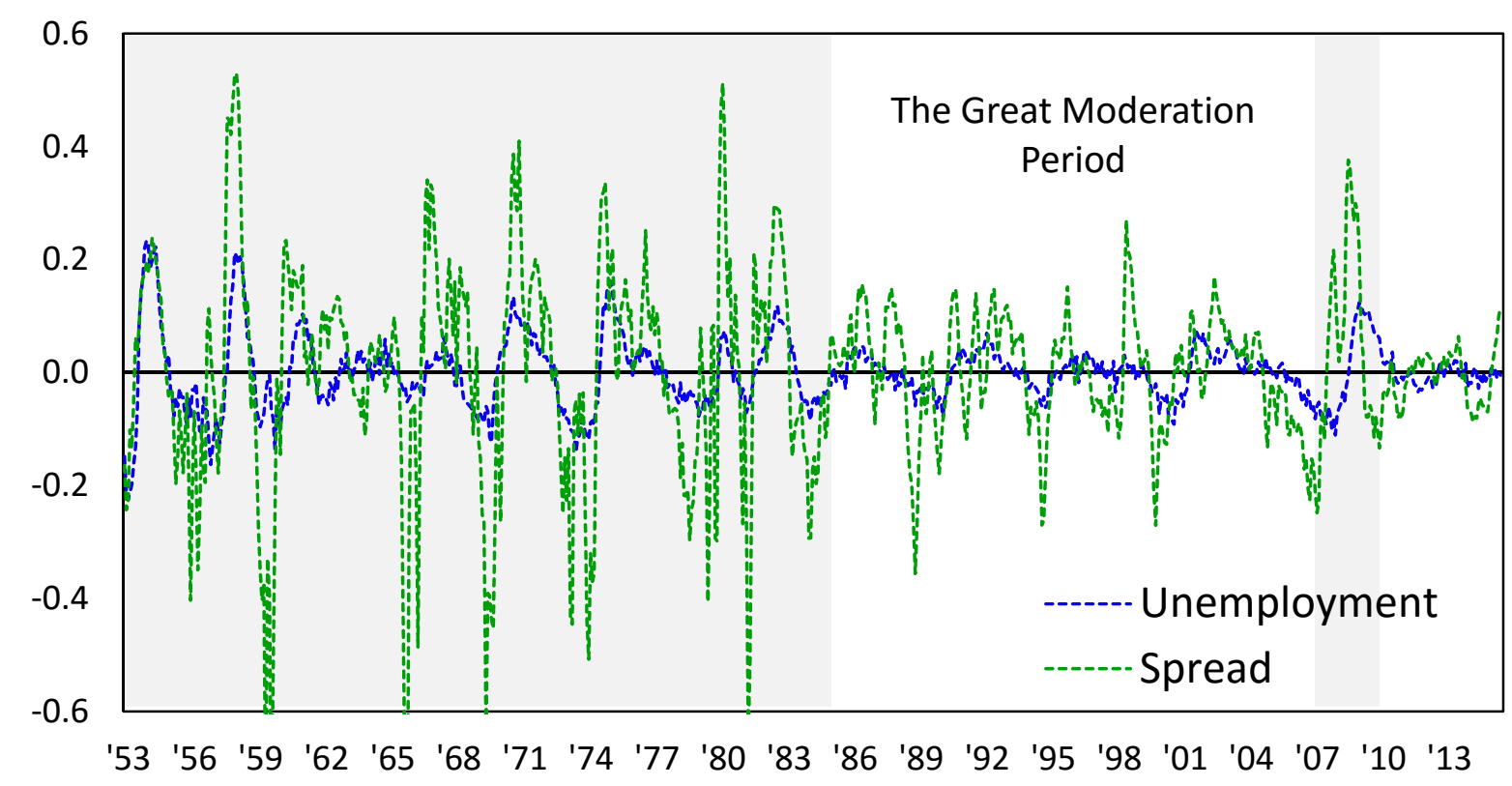

Source: FRED, BLS, FRED, BLS, an extension to Eckstein, Setty and Weiss (2015).

Notes: De-trended unemployment rate obtains through HP-filter, in SD. Bond yield spread is defined as the difference between two things: 5-Year Treasury Constant Maturity Rate, and Moody's Seasoned Baa Corporate Bond Yield, HP filtered, in SD.

Global inflation declined from 30 percent to 4 percent between 1993 and $2003 .{ }^{9}$ Rogoff (2003, 2004) conjectures that globalization - interacting with deregulation and privatization-has played a strong supporting role in the past decade's disinflation. An important feature of openness relates to international labor flows. International migrants constituted 2.9 percent of the world population in the 2000s, up from 2.1 percent in 1975. In some countries, changes have been more dramatic. In Israel in the 1990s, there was a surge of immigrants of up to 17

\footnotetext{
${ }^{9}$ Kenneth Rogoff's paper was prepared for the Federal Reserve Bank of Kansas City conference on "Monetary Policy and Uncertainty: Adapting to a Changing Economy" Jackson Hole, WY, August 29, 2003.
} 
percent of the population, and the central bank achieved a sizable decline of inflation. It is possible that the two events are related. In Spain in 1995, the percentages of foreigners in the population and in the labor force were below 1 percent and below 0.5 percent. At the end of 2006, these rates were around 9 percent and 14 percent.

By easing labor bottlenecks, migrants help to keep down prices of goods and services. Pass through of world low inflation, and low interest rates, to domestic prices and interest rates, the effects of migration on wages, is to be addressed by the standard Phillips curve analysis. $^{10}$

Independence of central banks is a way to overcome dynamic inconsistency: Expected inflation leads to output, employment, and financial-market distortions; surprise inflation is employment and output boosting (through the Phillips Curve mechanism). In the absence of central bank independence, the non-commitment equilibrium is one of high-expected inflation. Central bank independence is a necessary condition for overcoming the dynamic inconsistency and consequently weakening the inflation bias. Accordingly, Rogoff $(2003,2004)$ attributes the moderation in world inflation to a broad-based move towards having them run by conservative anti-inflation oriented central bankers; similar developments happened also in Israel. The increased competitiveness was a result of the interplay of globalization, deregulation and a decreased role for governments in many economies. Given this diagnosis he foresaw continued disinflation and even deflationary pressures (which came into a stark relief in the Great Recession) arguing that the most important factor supporting world-wide disinflation has been the mutually reinforcing mix of goods market and financial deregulation

\footnotetext{
${ }^{10}$ Bentolila, Dolaldo, and Jimeno (2007) have addressed the impact of the Spanish immigration boom on the Phillips curve.
} 
and globalization, and the consequent significant reduction in monopoly pricing power. These developments increased competitiveness; diminishing the gains, a central bank can reap via unanticipated inflation, because it reduces the gap between the economy's monopolistically competitive equilibrium, and the more socially desirable competitive equilibrium. In addition, both theory and empirics suggest that economies that are more competitive have more flexible nominal prices, making smaller the Barro-Gordon-type output gain the central bank can achieve by inflating; and making them more ephemeral. In a standard, stylized political economy model, Rogoff shows that it is easier to credibly sustain low inflation in a competitive than in a highly monopolistic economy. ${ }^{11}$

Evidence of the effect of globalization on the Phillips curve is provided by Loungani, Razin, and Yuen (2001), Razin and Loungani (2007), and Clarida (2008). Previously, Romer (1993, 1998) and Lane (1997) showed that inflation and trade liberalization are negatively (significantly) correlated among the large (flexible exchange rate) OECD economies.

The core mechanism in the New Keynesian paradigm depends on the Phillips Curve; that is, the tradeoff between surprise inflation and the level of economic activity. The reason why the New Keynesian framework is capable of generating such a trade-off between inflation and economic activity is that producer-desired prices (once prices are adjusted) rise with the economy's output,

\footnotetext{
${ }^{11}$ Rogoff's prediction has proven correct. Global inflation moved sideways also after 2003, and then fell sharply asymptotically, approaching zero after 2008, despite massive monetary and credit expansion in the United States and the European Union.
} 
when marginal costs slope upward due to diminishing returns to scale. Furthermore, when the labor supply increases, workers tend to experience increasing marginal disutility of labor efforts. The resulting increased real-wage demands must rise. Increased wage demands put an upward pressure on the marginal cost, and consequently on the producer-desired price setting.

Bean (2006) succinctly summarizes the effect of globalization on the Phillips curve in the era of globalization:

"One of the most notable developments of the past decade (that is, the 1990s) has been the apparent flattening of the short-run trade-off between inflation and activity. The seventies were characterized by an almost vertical relationship in the United Kingdom, in which attempt to hold unemployment below its natural rate resulted in rising inflation. In the eighties, the downward sloping relationship reappears, as inflation was squeezed out of the system by the slack of the economy. However, since the early nineties, the relationship looks to have been rather flat. Three factors-increased specialization; the intensification of product market competition; and the impact of that intensified competition and migration on the behavior of wages - should all work to flatten the short-run trade-off between inflation and domestic activity." 12

Evidently, changes in the foreign price pass through into domestic inflation in the open-economy case even if the exchange rate depreciation trend does not change. If, in addition, the exchange

\footnotetext{
${ }^{12}$ Similarly, Mishkin (2007) writes about the U.S. inflation-output trade-off: "The finding that inflation is less responsive to the unemployment gap, suggests that fluctuations in resource utilization will have smaller implications for inflation than used to be the case. From the point of view of policy makers, this development is a two-edged sword: On the plus side, it implies that an overheating economy will tend to generate a smaller increase in inflation. On the negative side, however, a flatter Phillips curve also implies that a given increase in inflation will be more costly to wring out of the system."
} 
rate depreciation tapers down, and once the foreign exporters to the home country are also given a chance to adjust prices in response to the moderation in the exchange rate depreciation, the home country import price inflation moderates as well. In the world of the Great Moderation the home country inflation abates.

Opening up of the economy to capital, goods, and labor mobility also flattens the Phillips curve. In the New Keynesian framework, Binyamini and Razin (2010) show how increased volume of trade in goods, greater financial openness, and labor migration affect the trade-off between output and inflation by flattening the Phillips curve. ${ }^{13}$ Minimizing the (utility-based) loss function implies moderate inflation, akin to the Great Moderation. They demonstrate analytically how the opening up of the domestic economy to trade in goods, international borrowing and lending and migration flatten the Phillips Curve (see Appendix). Every successive round of the opening up of the economy contributes to flatten the aggregate supply curve. The intuition is that when an economy opens up to trade in goods, it tends to specialize in production but to diversify in consumption. This means the number of domestically produced goods, is less than the number of domestically consumed goods. Consequently, the commodity composition of the consumption and output baskets, which are identical if the trade account is closed, are different when trade in goods is possible. As a result, the correlation between fluctuations in output and in consumption (which is equal to unity in the case of a closed trade account) is less than unity if the economy opens up to international trade in goods. The decomposition of utility based Phillips Curve to the various forces of migration, output gap, and real exchange rate is shown in an Appendix. In words, these globalization forces work analytically as follows.

\footnotetext{
${ }^{13}$ See Appendix.
} 
When the capital account is open, then the correlation between fluctuations in consumption and domestic output is further weakened, this is because with open capital accounts the representative household can smooth consumption through international borrowing and lending and thereby separate current consumption from current output. The inflation effects of shocks to the marginal cost are therefore reduced, because the fluctuations in labor supply are also smoothed, because of the consumption smoothing.

When the labor market is internationally closed to outward-migration, wage demands faced by domestic producers are upward sloping, both under in-migration and under a completely closed labor market. However, when the labor market is open to in-migration, domestic producers face an expanded labor supply: additional to the skilled native-born labor supply (with upward sloping wage demand), they also face a complementary unskilled foreign labor supply (with exogenously determined wage demand). That means that in-migration acts on the Phillips Curve essentially like a domestic productivity shock.

There has been some evidence of greater restraints on domestic prices and wage growth in sectors more exposed to international competition, such as textiles and electronics. Chen, Imbs, and Scott (2004) analyzed disaggregated data for EU manufacturing over the period 1988-2000. They find that increased openness lowers prices by reducing markups and by raising productivity. In response to an increase in openness, markups show a steep short-run decline, which partly reverses later, while productivity rises in a manner that increases over time. If globalization reduces the markup, our model predicts that this effect, by itself, leads to a more forceful anti-inflation policy and lessens the attention given by the policy maker to the fluctuations in economic activity. One can conjecture that more frequent price updating steepens the trade-off between inflation and activity; however, to our knowledge, neither theory nor empirical evidence exists in support of any 
systematic relationship between globalization and frequency of price updating. Notably, Gopinath and Rigobon (2007) report that the time frequency of price adjustment of U.S. imported goods trended downward, on average, during the Great Moderation. Gopinath and Itskhoky (2008) exploit the open economy environment, which provides a well-identified cost shock; namely sizeable exchange rate shocks. They use this identification method to test the effects of priceadjustment frequencies and pass through. They demonstrate that high frequency adjusters have a long-run pass-through that is at least twice as high as low frequency adjusters in the data are. Borio and Filardo (2007) present cross-country evidence in support of their contention that global factors have recently become empirically more relevant for domestic inflation determination. ${ }^{14}$

\subsection{Switch from two to one-digit inflation}

There are several countries, including Israel that went through hyperinflation crisis in some stage of their development. Following the 1977 change of guards at the government level (the political "Ha'Mahapach") in Israel, the newly elected "Likkud" government abruptly eased its control over the economy. In particular, capital controls largely lifted, initially bringing in short-term capital, followed later by a reversal when the economy faltered. At the same time, a populist economic

\footnotetext{
${ }^{14}$ See Binyamini and Razin (2010). See also Gali (2008) for a comprehensive treatise of the open-economy New Keynesian model. Borio and Filardo (2007) present cross-country evidence in support of their contention that global factors have recently become empirically more relevant for domestic inflation determination. But Ihrig et al. (2007) have shown that their result is very specific to the econometric method used. Based on cross-country analysis, Badinger (2007) finds that globalization is also correlated with more aggressive policy toward inflation. Tetlow and Ironside (2007), although not dealing with globalization, find that for the United States, the slope of the Phillips curve has - largely and continuously - lessened during recent years. However, Ihrig et al. (2007) have shown that results are very specific to the econometric method used. Based on cross-country analysis, Badinger (2007) finds that globalization is also correlated with more aggressive policy toward inflation. Tetlow and Ironside (2007), although not dealing with globalization, find that for the United States, the slope of the Phillips curve has-largely and continuously_-lessened during recent years.
} 
policy led to high budget deficits and big wage increases. The absence of constraining rules on actions of the central bank rendered it strongly accommodating the treasury in its expansionary monetary policy. With improper bank regulation, ("Visut Menayot") banks were on the verge of collapsing. All these led to a hyperinflation, which climaxed in mid-1985. Following the hyperinflation crisis in the early 1980s under the populistic "Likkud" government, a major political restructuring in Israel toward the political center enabled a unity government ("Likkud" plus "Avoda") to stabilize the economy. Indeed, some key measures, requiring a political consensus were taken and new legislation helped to immunize, in part the economy from similar extreme crisis features. In particular, a new legislation ("khok Hahesderim") allowed the government to exercise more tight control over the budget. A new law forbade the Central Bank to monetize the budget deficit ("Khok Iee Hadpassa"). A Tri-Party agreement between the government, the Federation of Labor ("Histadrut") and the association of private sector employers dampened the wage-price dynamics and enabled a sharp nominal devaluation that ended in a real devaluation. ${ }^{15}$

The macroeconomic changes, brought about by the stabilization program, have lasted until these very days. The Hyperinflation episode has not reoccurred. ${ }^{16}$ The 1985 inflation stabilization program laid the foundation for the increasing independence of central banks. Such independence is critical for the successful conquest of inflation (see Chapter 1). We document how a strong was

\footnotetext{
${ }^{15}$ The expectations-based framework whereby a change in monetary and fiscal regime help conquest inflation is in Sargent, (1999).

${ }^{16}$ Oil consuming developed economies, hit by the oil price shock like Israel, however were able to crush the nascent inflation pressures. Other developing countries experienced similar hyperinflation episodes. Many Latin American countries, particularly Argentine in 2002, went through similar processes. The 1997 Asian crisis had also similar features, except that a more disciplined fiscal policy had been maintained before the crisis erupted.
} 
the correlation between the convergence to advanced countries' inflation and the globalization process; both took a sharp upturn in the mid-1990s.

\subsection{Convergence of inflation rates}

Globalization-interacting with deregulation and privatization — has played a strong supporting role in Israel's disinflation. The moderation is due to a large extent to the increasing independence of the Bank of Israel, conducting effective anti-inflation policies in the presence of worldwide disinflation. ${ }^{17}$

Figure 2.1 shows the convergence of Israel inflation rate to US, Germany and OECD rates. Inflation fall started after the 1985 inflation stabilization policy but converged to the low one-digit rates of advanced economies in the 1990s. ${ }^{18}$

${ }^{17}$ Globalization affected also conduct of central banks. Inflation targeting was born in New Zealand in 1990. Admired for its transparency and accountability, it achieved success there, and soon in Canada, Australia, the UK, Sweden and Israel. It subsequently became popular as well in Latin America (Brazil, Chile, Mexico, Colombia, and Peru) and in other developing countries (South Africa, South Korea, Indonesia, Thailand and Turkey, among others).

${ }^{18}$ Leiderman (1999) comprehensively analyze Israel's dis-inflation with a focus on monetary policies related to inflation and disinflation in Israel. He especially focus on inflation targeting as an instrument of disinflation. 
Figure 2.1: Inflation Rates (Annual GDP Deflator, percentage)

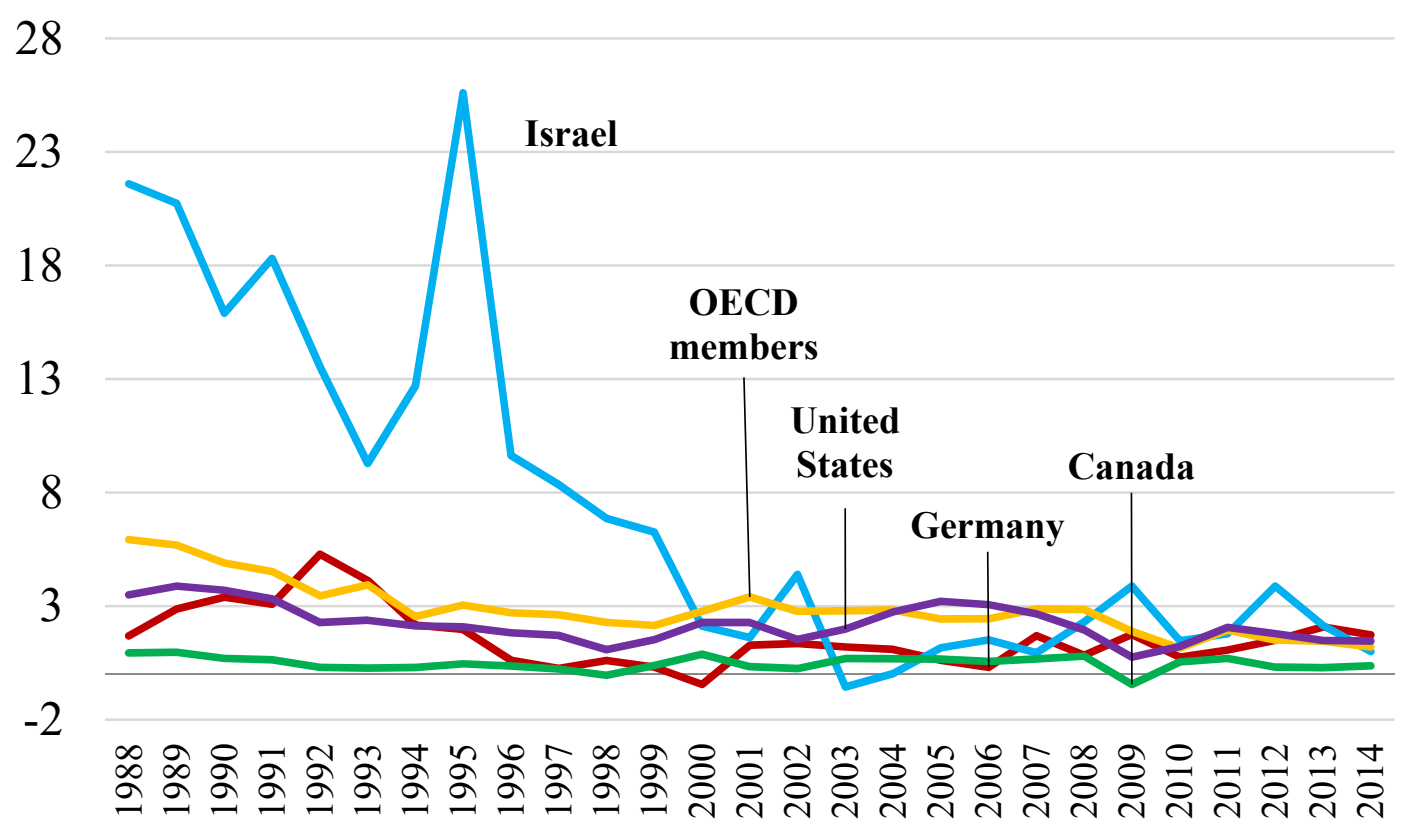

Source: The World Bank

(i) International Financial Integration

Full international financial integration requires that in the long run (when prices adjust to various shocks and markets clear), the following arbitrage equation holds.

$$
1+r_{t}^{U S}=\left(1+r_{t}^{i}\right) \frac{q_{i / U S, t+1}}{q_{i / U S, t}}
$$

Where $i$ stands for Israel, Canada, Germany and the United Kingdom; and q stands for the real exchange rate vis a vis the US dollar ${ }^{19}$ :

${ }^{19}$ Recall that by the Fisher equation:

$$
1+r_{t}^{U S}=\left(1+i_{U S}^{t}\right) \frac{P_{U S, t}}{P_{U S, t+1}} \text {, That is, }\left(1+r_{t}^{i}\right) \frac{q_{i / U S, t+1}}{q_{i / U S, t}}=\left(1+i_{i}^{t}\right) \frac{P_{i, t}}{P_{i, t+1}} \frac{q_{i / U S, t+1}}{q_{i / U S, t}} .
$$




$$
q_{i / U S, t}^{t}=E_{i / U S, t} \frac{P_{U S, t}}{P_{i, t}},
$$

In addition, $E$ stands for the nominal exchange rate, vis a vis the US dollar; and $P$ stands for the price level.

Figure 2.2 plots the graphs of the real-interest-rate, adjusted for real exchange rate changes, the yields on three-month government bonds for Israel, Canada, Germany and the United Kingdom, and the yields on three-month US government bonds. International financial integration generates more synchronized country-specific yields. Time series are filtered to wash out short-run idiosyncratic fluctuations. Figure 2.2 demonstrates strikingly that in the $1990 \mathrm{~s}$ Israel integrate significantly into the world financial markets. 
Figure 2.2: Gross Real Interest Rate Adjusted for Real Exchange Rate Changes (US benchmark)

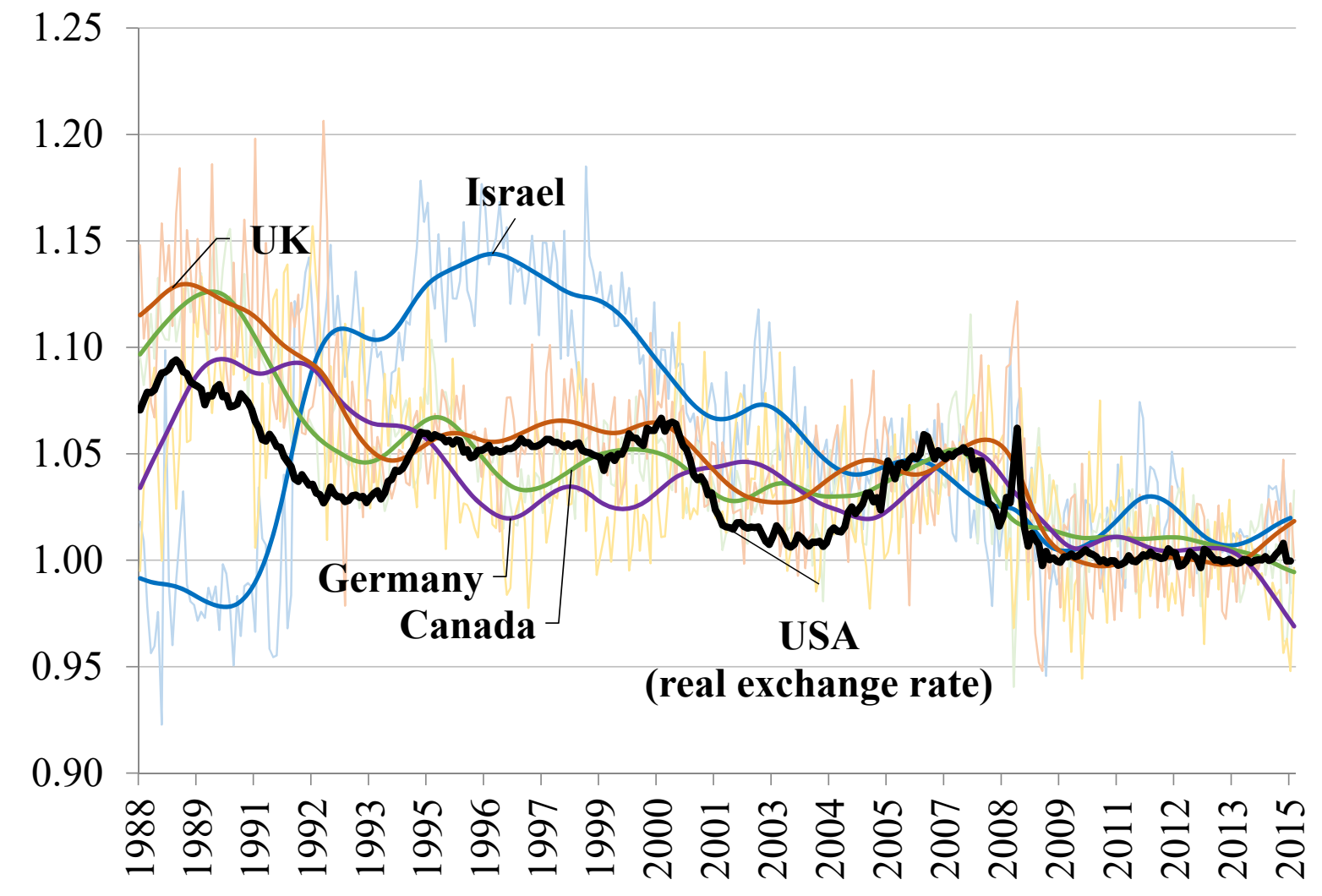

Note: Series are HP-filtered. Monthly data are shown in the background.

Source: Stats Bureau, FERD, World Bank, Real-exchange-rate adjusted, yields on threemonth government bonds for Israel, Canada, Germany and the United Kingdom, and the yields on three-month US government bonds.

\subsection{Implications}

The absence of constraining rules on actions of the Bank of Israel and on Israel's fiscal authority has induced strongly accommodative monetary policies and uncontrolled inflation. With improper financial sector regulation, (e.g., the so-called "Visut Menayot") banks were on the verge of collapsing in the 1984 crisis. They were able to recapitalize making their investment portfolios less risky over the next two decades, thanks to more rigorous bank regulations. 


\section{Depression-Deflation Resistance}

Israel's resilience to the external financial shock during the global crisis is rooted in (a) the absence of credit boom in the wake of the crisis, and (b) the relatively small commercial banks' exposure in terms of toxic assets that for the European countries played a major role.

The newly emerging macroeconomic paradigm spans the gamut from an analytical framework that features full capital-market arbitrage, smooth credit, Ricardian-equivalence properties, representative agents, and efficient monetary management, to a framework with multiple agents, incorporating debt frictions, liquidity traps, and relatively ineffective monetary management and provides a role for fiscal policy in aggregate demand management. The analytical framework based on the frictionless paradigm captures well the role of globalization forces and the reduction in inflation in the 1990s Great Moderation era. The multiple-agent, market-friction revised analytical framework captures some key features of the Great Recession that occurred in the aftermath of the 2008 global financial crisis. It gives insight about the macroeconomic effects of debt overhang on economic activity and inflation, when the monetary policy rate reaches its lower bound.

The concern at the time was that Israel, being well integrated in to the world markets and the world finance, might suffer contagion that will be long lasting. At the end of the day, Israel suffered only a temporary trade shock because of the decline in world demand. 
As shown in figure 3.1, Israel did not have a significant credit boom in the wake of the 2008 crisis.

The US and the UK, in contrast, were vulnerable to a gigantic credit expansion (Germany, as if Israel escaped such credit bubbles).

\section{Figure 3.1: Domestic Credit to Private Non-Financial Sector (\% of GDP)}

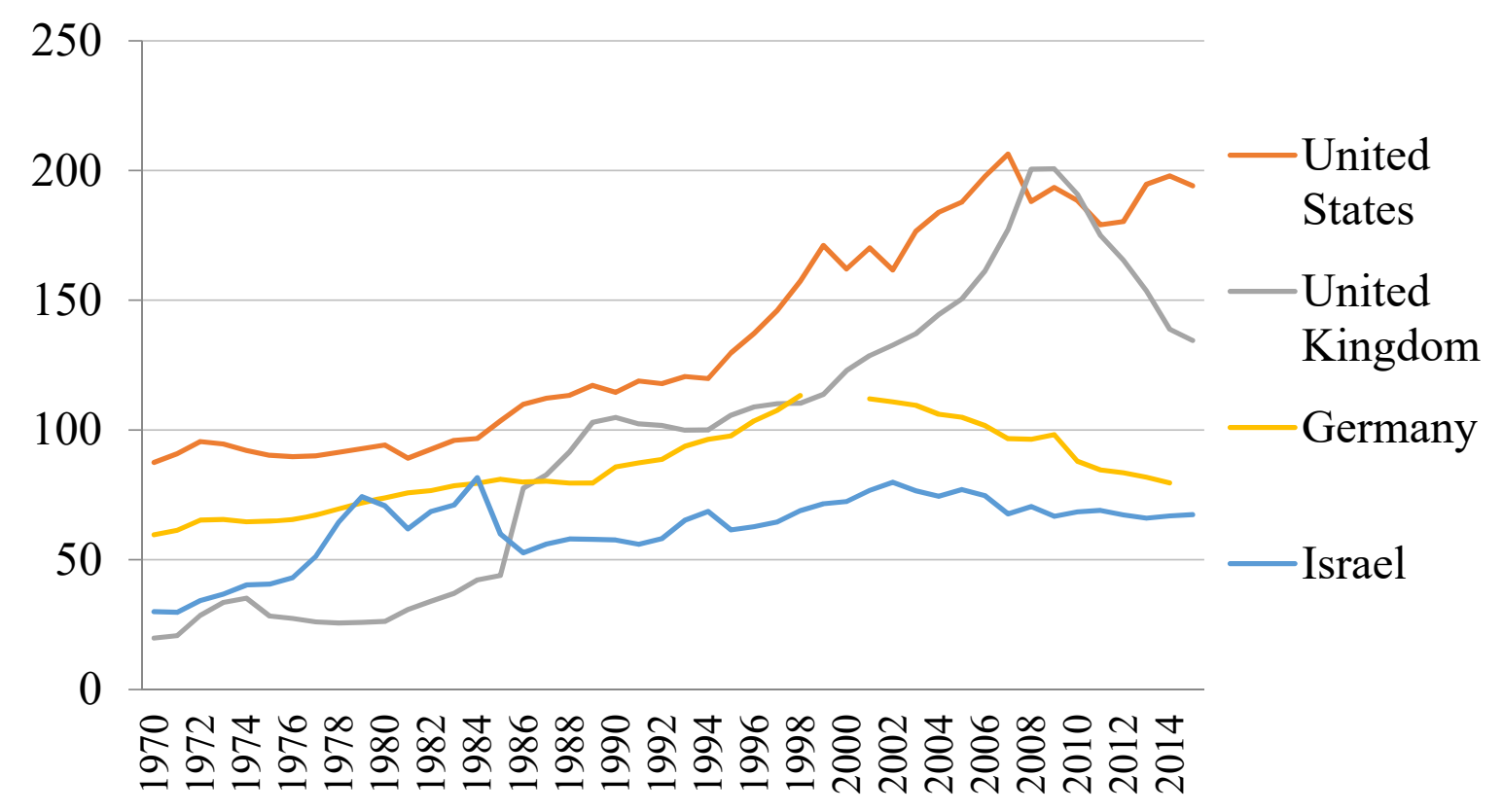

Source: International Monetary Fund, International Financial Statistics, data files, and World Bank and OECD GDP estimates.

Note: Domestic credit provided by the financial sector includes all credit to various sectors on a gross basis, with the exception of credit to the central government, which is net. The financial sector includes monetary authorities and deposit money banks, as well as other financial corporations where data are available (including corporations that do not accept transferable deposits but do incur such liabilities as time and savings deposits). Examples of other financial corporations are finance and leasing companies, moneylenders, insurance corporations, pension funds, and foreign exchange companies.

Nevertheless, GDP growth has averaged 4 percent over the 2005-2010 period years, compared with 0.7 percent on average for OECD countries. The overall living standards continue to improve gradually, with per capita real GDP growing more rapidly than in other OECD countries. The 
economy's resilience has been underpinned by solid economic fundamentals, including large foreign reserves, a dynamic high tech export sector, and the absence of economy wide deleveraging pressures leading to the downfall in economic activity. Because, Israel did not have a credit bubble in the years preceding the global financial crash, like the other major advanced economies, which burst during the financial crisis.

Israel's growth performance depicted in Figure 3.2, during and after the global crisis, however, was not unique. Figure 3.3 shows that among similar small open economies Israel's GDP grew over the recent 20 years, including the 2008-2010 period at a similar cumulative rate as Chile; but at a much higher rate than Greece, Spain and Portugal; which had a financial sector crash.

Figure 3.2: Real GDP, Israel and Selected Countries $($ Jan $2003=100)$

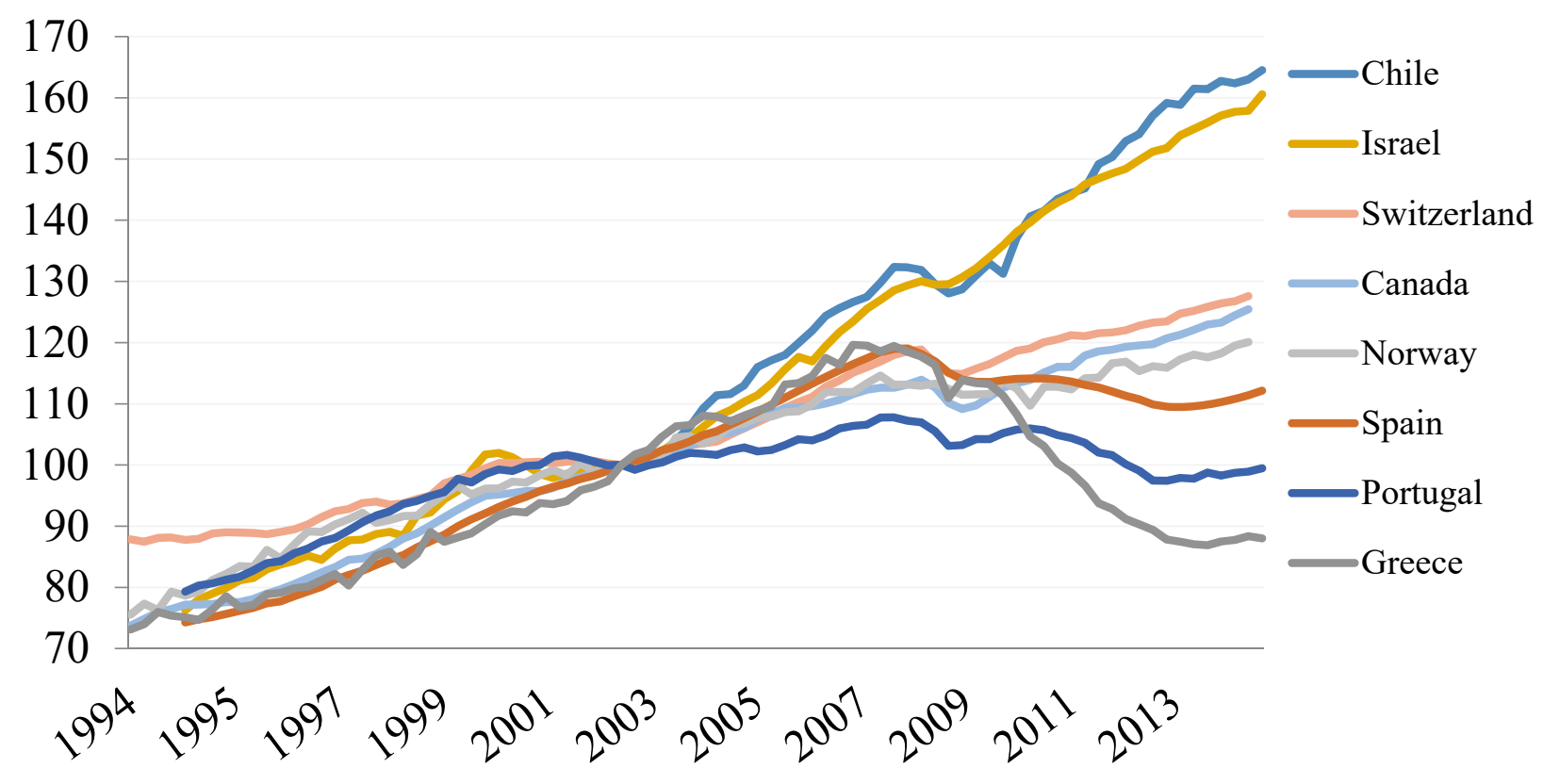

Source: FRED 
Furthermore, Figure 3.3 depicts GNP levels for Israel, Turkey, Brazil and Canada; economies, which spared financial, sector crash. Israel exhibits a more moderate drop of output than all these countries.

Figure 3.3: Real GNP, Countries with No Financial Crisis (January $1998=100)$

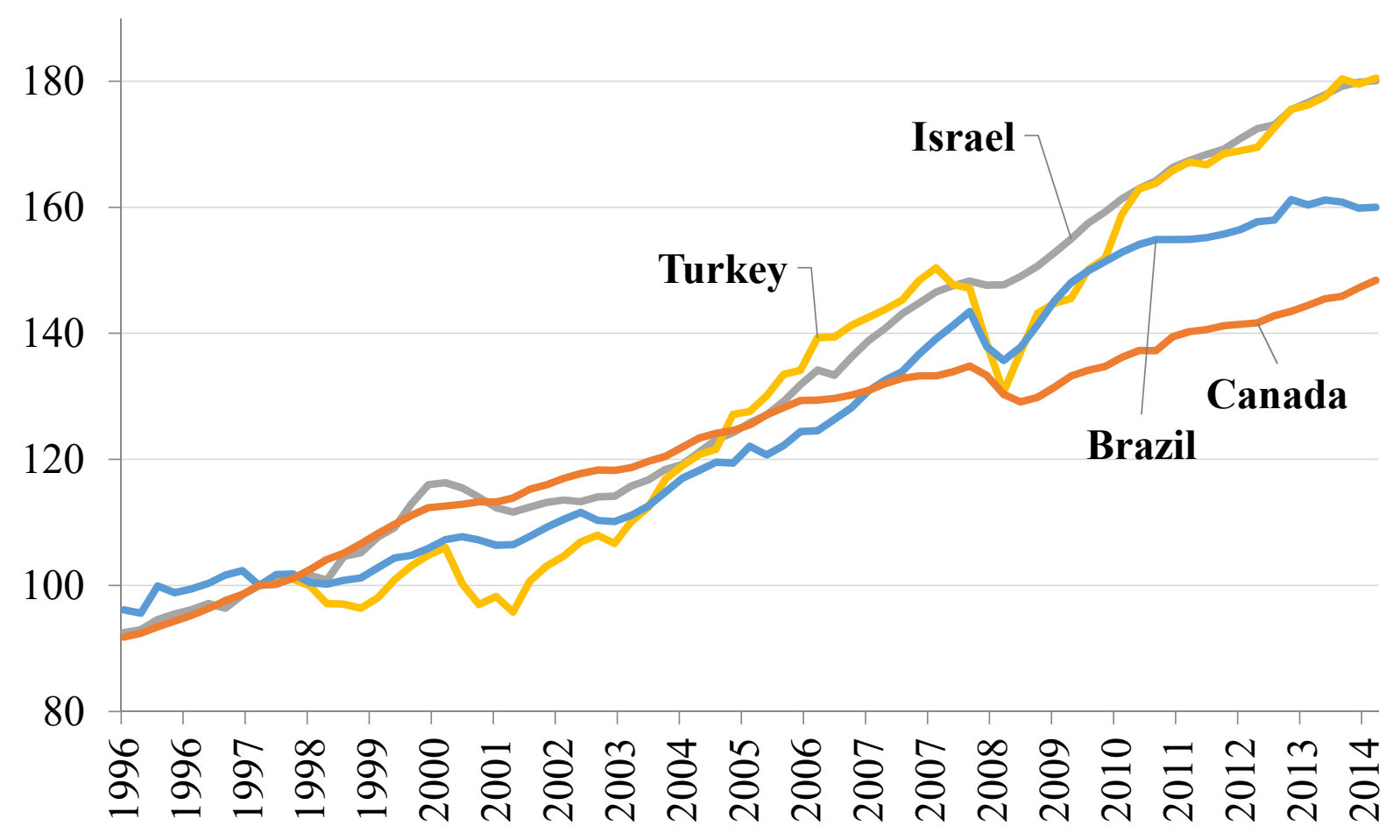

Source: FRED

\subsection{International Capital Flows}

Capital flows provide another measure of the resilience of the Israeli Economy to the shocks. In the aftermath of the global financial crisis, expansionary monetary policy in advanced economies conventional or unconventional, that were conducted to boost up the economy, has affected emerging market economies and others, such as Israel, through three channels:

(1) Reduced exports; 
(2) Exchange rate appreciation; and,

(3) Effects of capital inflows on the domestic financial system.

A number of studies have found an effect of monetary policy on specific gross flows. Bruno and Shin (2015) for example, using a VAR methodology over the pre-crisis period (1995:4 to 2007:4) find an effect of the federal funds rate on cross-border bank to bank flows; the effect is however barely significant. Fratzscher et al (2013), using daily data on portfolio equity and bond flows, find significant effects of different monetary policy announcements and actions since the beginning of the crisis. Their results however point to the complexity of the effects of apparently largely similar monetary measures. For example, they find QE1 announcements decreased bond flows to EMs, while QE2 announcements increased them. In terms of the equations above, this suggests that, in each case, monetary policy worked partly through its effects on the risk premium. These studies cannot settle the further issue of whether or not total gross inflows increase with advanced economies monetary expansions: The increase in the inflows the researchers have identified may be offset by a decrease in other inflows ${ }^{20}$. However, studies of total inflows, or of the set of inflows adding up to total inflows, yield some mixed conclusions. A representative and careful paper, by Cerutti et al (2015), using quarterly flows over 2001:2 to 2013:2, suggests two main conclusions. The most significant observable variable in explaining flows into Emerging Markets (EMs) is the VIX index ${ }^{21}$ : An increase in the VIX leads to a decrease in inflows to EMs. The coefficients on the monetary policy variables, namely the expected change in the policy rate and the slope of the

\footnotetext{
${ }^{20}$ See Blanchard (2016) who surveyed the literature about post 2008 crisis in advanced economies and emerging economies that were hit to different degrees by the global financial crisis. To a large extent, the emerging markets escaped the brunt of the crisis. Israel evidently belongs to the second group.

${ }^{21}$ The VIX is the Chicago Board Options Exchange Market Volatility Index. It is a measure of the implied volatility of S7P 500 index options. The VIX
} 
yield curve, typically have the expected sign. Several studies found that movements in the VIX are strongly associated with global capital flows. ${ }^{22}$

It is worth looking now at capital inflows to EMs and Israel from the US, the epicenter of the global financial crisis, and the country, which adapted with virtually no lag a brief expansionary fiscal policy and a persistent expansionary monetary policy.

Figure 2.6 describes the portfolio capital outflows from the US to selected countries. Israel is in the middle of the pack of countries that enjoy inflow of portfolio capital investments in the aftermath of the 2008 global financial crisis. These inflows put appreciation pressures on the exchange rates. Some central banks, including BOI, conducted a policy of a massive purchase of foreign currency denominated assets, to protect against the declining competitiveness in the world trade.

${ }^{22}$ See Rey (2015). 
Figure 3.4: Portfolio Flows, Crisis Economies (Index, Dec $1994=100$ )

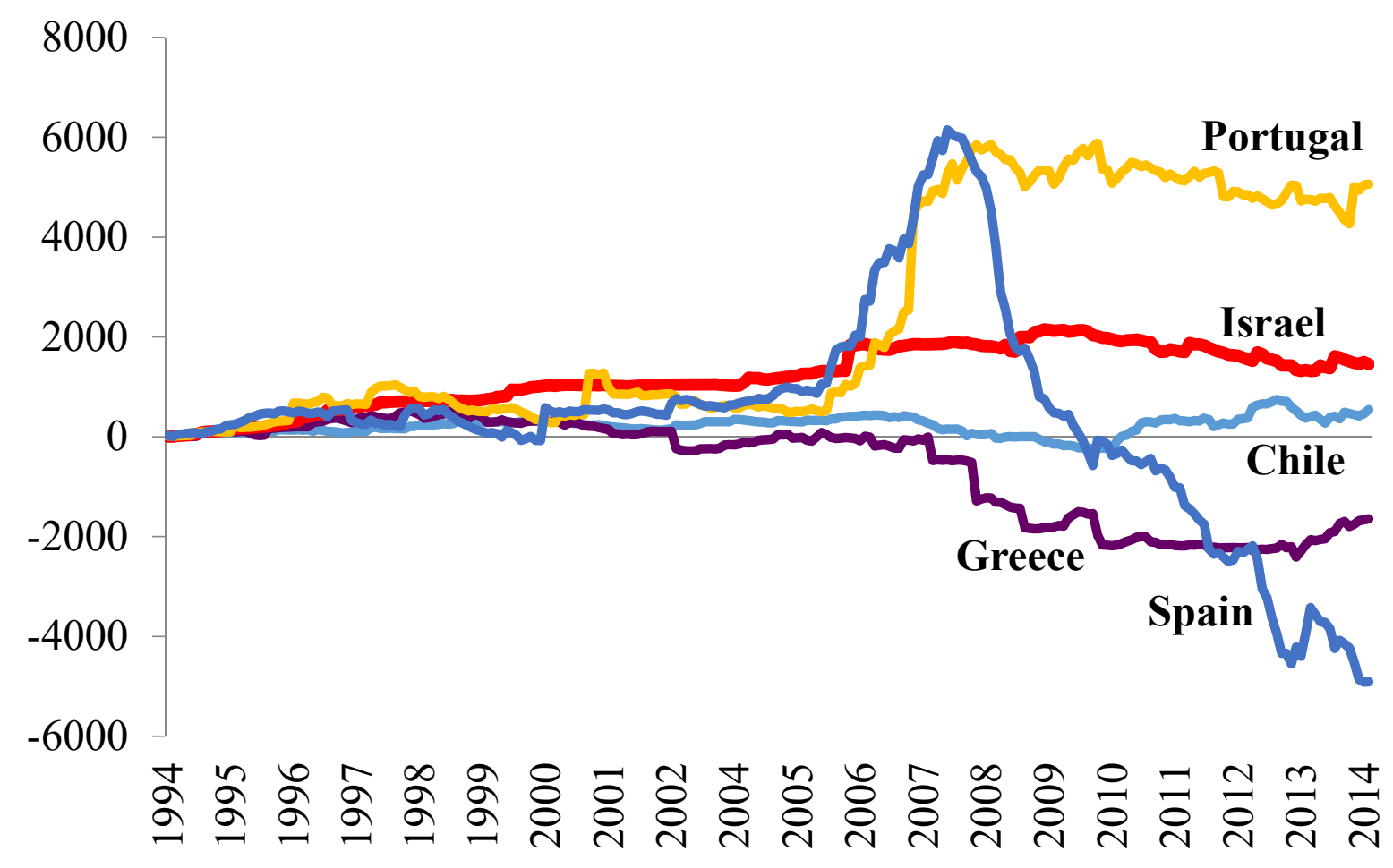

Source: Anusha Chari

\section{Exchange-Rate Policy Reaction}

How did the Israeli policy makers react to the 2008 world financial-depression, and global tradediminishing shocks? Policy makers' concern was three-fold: First, banks exposures to toxic assets such as mortgage based securities and foreigners' debt obligations. Partly because Israel skipped the credit bubble, and bank regulations were relatively tight, Israel showed a sound resilience to the global financial shock. Second, Israel export markets softened and demand conditions deteriorated. Third, Israel domestic currency was strengthened. Bank of Israel addressed the last two issues by a massive foreign exchange market intervention to weaken the value of the domestic currency, and stimulate exports. 
In the aftermath of the global financial crisis, expansionary monetary policy in advanced economies' conventional or unconventional, that were conducted to boost up the economy, has appreciated the currencies of the emerging market economies, including Israel. The question for these economies was whether an expansionary monetary policy, which tends to depreciate the currency and boost exports requires a direct foreign exchange market intervention, or whether the latter can succeed without the former. ${ }^{23}$

Israel monetary authorities were concerned about the "Great Recession" downward pressures on the demand for Israel's exports and the strengthening of the Israeli currency as capital inflows rose. They engaged in an intensive (sterilized) intervention in the foreign exchange market to prevent the appreciation of the currency. However, there is evidently limits to how much such policy can stimulate the demand for Israel's output.

Sterilized intervention is ineffective when there is high private capital mobility to the extent that domestic and foreign securities viewed by a large group of investors, are close substitutes. Conditions under which sterilized intervention is effective happen to exist for a crisis economy, however, when there is a probability of capital flow reversal, liquidity shortage, or major real trade shock, leading to financial-intermediaries collapse. (See Appendix 5B). Under conditions where foreign and domestic assets are close substitutes, sterilized intervention is ineffective. Through a central-bank sale of domestic government debt assets, following a purchase of foreign currency in the foreign exchange market, the money supply fully adjusts to bring back the pre-intervention

\footnotetext{
${ }^{23}$ In the presence of trending capital exports, the central bank cannot persistently appreciate the domestic currency by selling foreign exchange denominated assets in the foreign exchange market, because depleted international reserves could quickly reach their lower bound. However, In the presence of trending financial capital imports, the central bank can persistently depreciate the domestic currency by purchasing foreign exchange denominated assets in the foreign exchange market through money issue. This is why the foreign exchange market intervention is referred to as a "half instrument" in the hands of the central bank.
} 
expected rates of return on domestic and foreign currency bonds into equilibrium (the standard interest parity). Therefore, sterilized foreign- exchange-market intervention, by the monetary authorities, where the domestic money supply is unchanged, is incapable of pushing the exchange rate up or down. However, the proposition may change in the presence of imperfect asset substitutability, where domestic and foreign bonds command a different liquidity premium and risk premium. Changing the composition of central bank assets, between foreign and domestic assets (the case of sterilized foreign exchange rate market interventions), can then have real economic effects in the presence of credit market spreads and frictions. In this case, sterilized foreign-exchange-market intervention could effectively change the value of the foreign currency in terms of domestic currency. A sterilized purchase of foreign assets may change the liquidity premium that domestic bonds command, relative to foreign bonds, even though the money supply is left unchanged. A similar outcome may transpire when foreign exchange intervention changes market views of future foreign-exchange-market interventions. Similarly, liquidity-based imperfect asset substitution between domestic government and domestic private-sector bonds during liquidity crises can be exploited by the central bank. ${ }^{24}$ Israel's foreign exchange market half-decade episode started when credit frictions were relatively intensive following the Lehman moment in the USA in October 2008. As Appendix 5B indicates, under the conditions the intervention aimed at keeping the exchange-rate overly depreciated are effective. However, over time, as credit conditions improved, the policy became potentially less and less effective, as Appendix 4A demonstrates.

Recall that the most significant observable variable in explaining short-term flows into Emerging Markets (EMs) is the VIX index: An increase in the VIX leads to a decrease in inflows to EMs.

\footnotetext{
${ }^{24}$ See Krugman, Obstfeld and Melitz. (2015).
} 
The VIX index is directly related to the risk adjusted return on domestic government bonds in the periphery countries, like Israel. Sterilized foreign-exchange market purchase of US government bonds by the central bank is then capable of blocking exchange rate appreciation. This was the rationale for the Bank of Israel policy in the aftermath of the global financial crisis. However, the effectiveness of such policy is short lived. Once the VIX index falls, sterilized-foreign-exchangemarket intervention becomes ineffective. Excessively high foreign reserves also have fiscal medium term costs.

Figure 4.1 describes the changes in foreign exchange reserves for selected countries during the aftermath of the 2008 financial shock. Israel foreign exchange reserves grew significantly more than those of the advanced economies did but not much different from those among the non-OECD countries. ${ }^{25}$ Figure 5.7 describes the portfolio capital outflows from the US to selected countries. Israel is in the middle of the pack of countries that enjoy inflow of portfolio capital investments in the aftermath of the 2008 global financial crisis. These inflows put appreciation pressures on the exchange rates. Some central banks, including BOI, conducted a policy of a massive purchase of foreign currency denominated assets, to protect against the declining competitiveness in the world trade.

\footnotetext{
${ }^{25}$ The phenomenon of a group of countries intervening to retain undervalued exchange rate is often referred to as "currency war".
} 
Figure 4.1: Portfolio Flows, Crisis Economies (Index, Dec $1994=100$ )

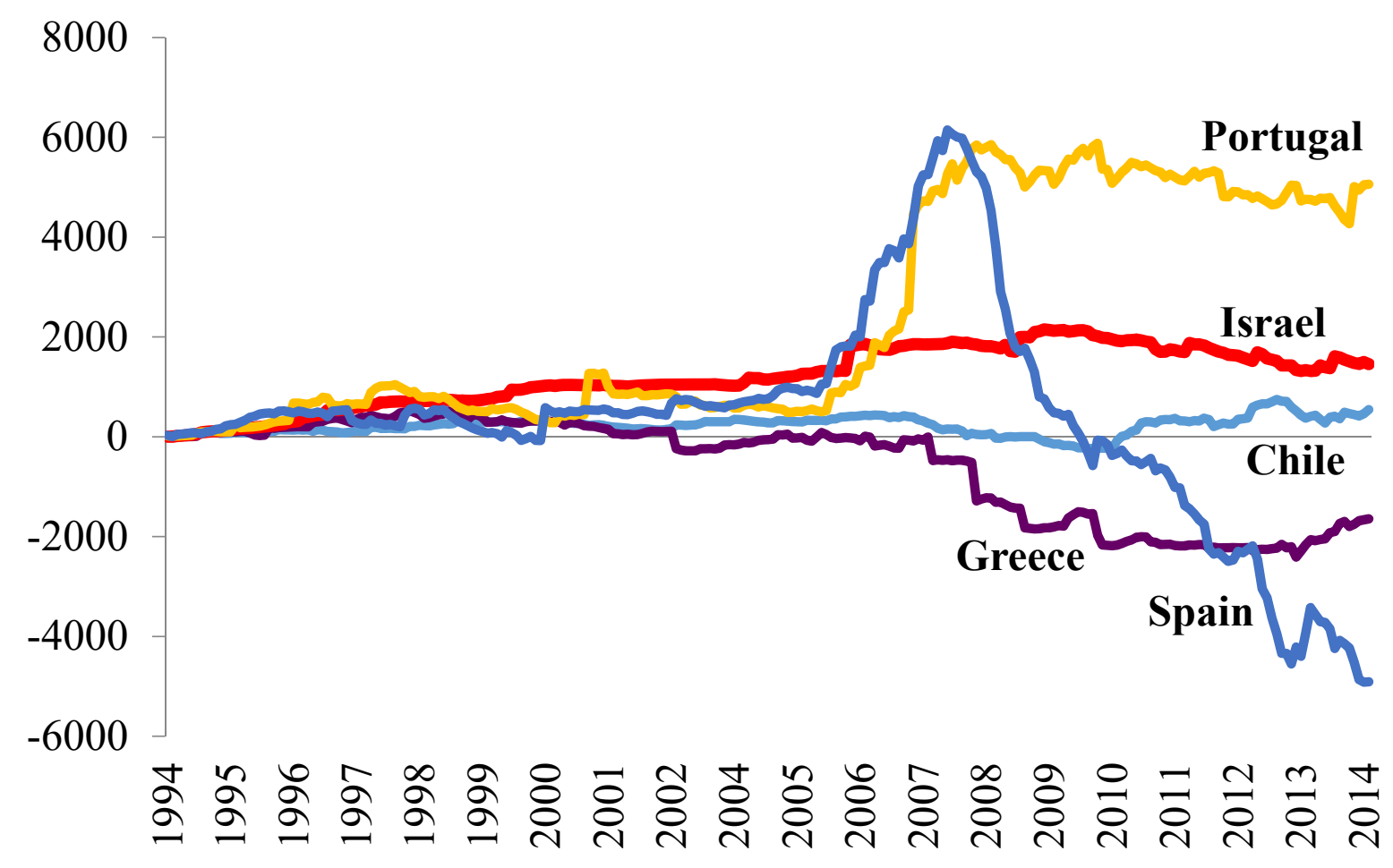

Source: Anusha Chari

Figure 2. describes the nominal exchange rate of various countries that engaged in the "currency war" period: Israel, Sweden, Switzerland, Brazil and Indonesia. Israel seems to have undervalued its currency the least among these countries; possibly because thanks for its international financial integration and almost no capital controls, the effectiveness of sterilized intervention was weak.

\subsection{Leaning against the Winds}

How did the Israeli policy makers react to the 2008 world financial-depression, and global tradediminishing shocks? Policy makers' concern was three-fold: First, banks exposures to toxic assets 
such as mortgage based securities and foreigners' debt obligations. Partly because Israel skipped the credit bubble, and bank regulations were relatively tight, Israel showed a sound resilience to the global financial shock. Second, Israel export markets softened and demand conditions deteriorated. Third, Israel domestic currency was strengthened. Bank of Israel addressed the last two issues by a massive foreign exchange market intervention to weaken the value of the domestic currency, and stimulate exports.

In the aftermath of the global financial crisis, expansionary monetary policy in advanced economies' conventional or unconventional, that were conducted to boost up the economy, has appreciated the currencies of the emerging market economies, including Israel. The question for these economies was whether an expansionary monetary policy, which tends to depreciate the currency and boost exports requires a direct foreign exchange market intervention, or whether the latter can succeed without the former. ${ }^{26}$

Israel monetary authorities were concerned about the "Great Recession" downward pressures on the demand for Israel's exports and the strengthening of the Israeli currency as capital inflows rose. They engaged in an intensive (sterilized) intervention in the foreign exchange market to prevent the appreciation of the currency. However, there is evidently limits to how much such policy can stimulate the demand for Israel's output.

Sterilized intervention is ineffective when there is high private capital mobility to the extent that domestic and foreign securities viewed by a large group of investors, are close substitutes.

\footnotetext{
${ }^{26}$ In the presence of trending capital exports, the central bank cannot persistently appreciate the domestic currency by selling foreign exchange denominated assets in the foreign exchange market, because depleted international reserves could quickly reach their lower bound. However, In the presence of trending financial capital imports, the central bank can persistently depreciate the domestic currency by purchasing foreign exchange denominated assets in the foreign exchange market through money issue. This is why the foreign exchange market intervention is referred to as a "half instrument" in the hands of the central bank.
} 
Conditions under which sterilized intervention is effective happen to exist for a crisis economy, however, when there is a probability of capital flow reversal, liquidity shortage, or major real trade shock, leading to financial-intermediaries collapse.. Under conditions where foreign and domestic assets are close substitutes, sterilized intervention is ineffective. Through a central-bank sale of domestic government debt assets, following a purchase of foreign currency in the foreign exchange market, the money supply fully adjusts to bring back the pre-intervention expected rates of return on domestic and foreign currency bonds into equilibrium (the standard interest parity). Therefore, sterilized foreign- exchange-market intervention, by the monetary authorities, where the domestic money supply is unchanged, is incapable of pushing the exchange rate up or down. However, the proposition may change in the presence of imperfect asset substitutability, where domestic and foreign bonds command a different liquidity premium and risk premium. Changing the composition of central bank assets, between foreign and domestic assets (the case of sterilized foreign exchange rate market interventions), can then have real economic effects in the presence of credit market spreads and frictions. In this case, sterilized foreign-exchange-market intervention could effectively change the value of the foreign currency in terms of domestic currency. A sterilized purchase of foreign assets may change the liquidity premium that domestic bonds command, relative to foreign bonds, even though the money supply is left unchanged. A similar outcome may transpire when foreign exchange intervention changes market views of future foreign-exchange-market interventions. Similarly, liquidity-based imperfect asset substitution between domestic government and domestic private-sector bonds during liquidity crises can be exploited by the central bank. ${ }^{27}$ Israel's foreign exchange market half-decade episode started when credit frictions were relatively intensive following the Lehman moment in the USA in October

\footnotetext{
${ }^{27}$ See Krugman et al. (2015).
} 
2008; intervention aimed at keeping the exchange-rate overly depreciated are effective. However, over time, as credit conditions improved, the policy became potentially less and less effective.

Recall that the most significant observable variable in explaining short-term flows into Emerging Markets (EMs) is the VIX index: An increase in the VIX leads to a decrease in inflows to EMs. The VIX index is directly related to the risk adjusted return on domestic government bonds in the periphery countries, like Israel. Sterilized foreign-exchange market purchase of US government bonds by the central bank is then capable of blocking exchange rate appreciation. This was the rationale for the Bank of Israel policy in the aftermath of the global financial crisis. However, the effectiveness of such policy is short lived. Once the VIX index falls, sterilized-foreign-exchangemarket intervention becomes ineffective. Excessively high foreign reserves also have fiscal medium term costs.

Figure 4.2 describes the changes in foreign exchange reserves for selected countries during the aftermath of the 2008 financial shock. Israel foreign exchange reserves grew significantly more than those of the advanced economies did but not much different from those among the non-OECD countries. The Figure describes the nominal exchange rate of various countries that engaged in the "currency war". period: Israel, Sweden, Switzerland, Brazil and Indonesia. Israel seems to have undervalued its currency the least among these countries; possibly because thanks for its international financial integration and almost no capital controls, the effectiveness of sterilized intervention was weak ${ }^{28}$.

\footnotetext{
${ }^{28}$ The phenomenon of a group of countries intervening to retain undervalued exchange rate is often referred to as "currency war".
} 
Figure 4.2: Nominal Exchange Rate of Various Countries that Engaged in the "Currency War" Game: Israel, Switzerland, Sweden, Brazil and Indonesia (2007=100)

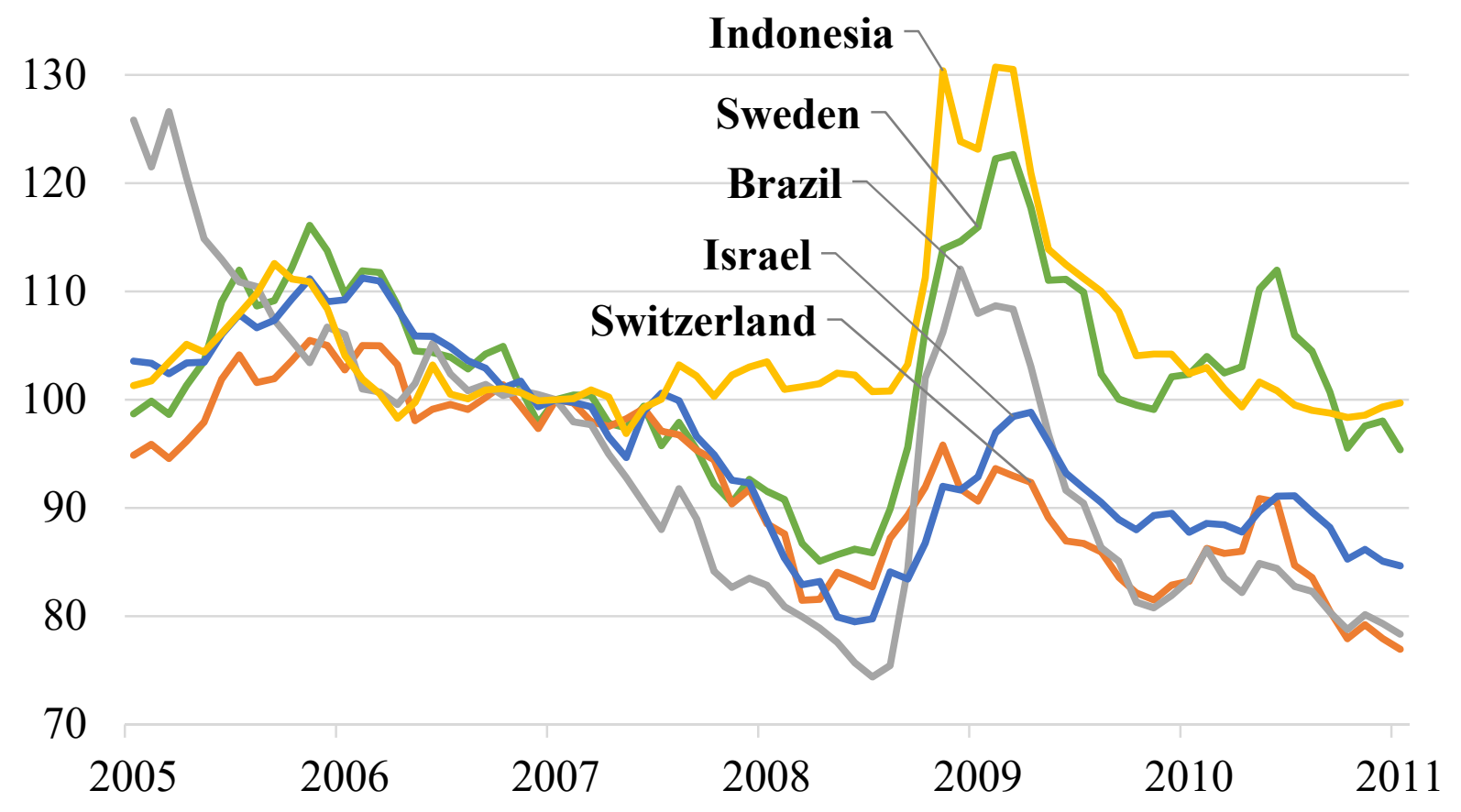

Source: FRED

\subsection{Some Implications}

Historical patterns of booms and busts typically exhibit frequent small recessions interrupted by rare but deep and long recessions. Traditional macroeconomic models, used often by central banks and many other policy-making institutions, do not capture the full features of crises: frequent small recessions punctuated by rare depressions. They do not illuminate how small open economies, like Israel, which are substantially integrated into the world economy, perform when a global financial shock takes place, leading to recession as deep and persistent as the Great Recession. We discussed in this Section the relatively robust performance of Israel (as well as some other advanced economies (e.g., Canada), and major Emerging Markets in the aftermath of the 2008 global 
financial crisis. Factors contributing to this robustness are the absence of credit and real estate bubbles, and banks' tight regulation in the wake of the crisis, which precluded the deleveraging process following the financial crisis.

\section{Conclusion}

The state of Israel, founded in 1948, benefited immensely from the post-1945 globalization wave. Steadily reforming its financial and commercial institutions, and becoming increasingly globalized in trade, labor market, and finance, Israel became a member of the OECD; the accession took place in 2010. Currently, Israel's is a thriving economy, integrated tightly into the world economy, Israel also feature a remarkable technological prowess. The Israeli economy is a remarkable development success story. A middle-income economy in the midst of a hyperinflation in the early 1980s, Israel grew into one of the most thriving economies in the world: and this despite the ongoing security challenges, that are most certainly a drain on its resources. However, technology, globalization, and domestic policies created high income inequality. 


\section{Appendix: Globalization and the Phillips Curve}

Binyamini and Razin (2010) show how trade in goods, financial openness, and labor in- and outmigration affect the trade-off between output and inflation by successively flattening the Phillips Curve. In the case of perfect mobility of labor, capital, and goods, the log-linear approximate aggregate supply curve (Phillips Curve) is given by ${ }^{29}$ :

$$
\begin{aligned}
\widehat{\pi}_{t}= & \kappa \cdot\left[\frac{\omega_{p} \cdot n}{1+\omega_{p} \theta} \cdot x_{t}+\frac{\omega_{p} \cdot(1-n)}{1+\omega_{p} \theta} \cdot\left(\widehat{Y}_{t}^{F}-\widehat{Y}_{t}^{N}\right)+\frac{1}{1+\omega_{p} \theta} \cdot \widehat{w}_{t}^{W}+\frac{(1-n)}{n} \cdot \widehat{q}_{t}\right] \\
& +\frac{(1-n)}{n} \cdot\left(\widehat{q}_{t}-\widehat{q}_{t-1}\right)+\beta \cdot E_{t}\left[\widehat{\pi}_{t+1}-\frac{(1-n)}{n}\left(\widehat{q}_{t+1}-\widehat{q}_{t}\right)\right],
\end{aligned}
$$

where $\widehat{\pi}_{t}$ is the deviation of CPI inflation from its target; $x_{t} \equiv\left(\widehat{Y}_{t}{ }^{H}-\widehat{Y}_{t}{ }^{N}\right)$ is the domestic output gap; $\left(\widehat{Y}_{t}^{F}-\widehat{Y}_{t}^{N}\right)$ is the difference between foreign output and domestic natural output; the parameter $\omega_{p}$ is the elasticity of the marginal cost with respect to producer's output, $\theta$ is the intra industry elasticity of substitution, $\sigma$ stands for the intertemporal elasticity of substitution, and $\beta$.denotes the subjective discount factor. The term $\mathrm{n}$ denotes the mass (number) of domestically produced goods, w is domestic wage, and superscript F, N, and W, denotes Foreign, Natural and World variable, respectively.

\footnotetext{
${ }^{29}$ See also Razin (2014), Chapter 11.
} 
The term $\kappa=\frac{(1-\alpha)(1-\alpha \beta)}{\alpha}$, captures the degree of price flexibility; and $(1-\alpha)$ is the probability of receiving a price-updating signal. The variable $\hat{q}_{t}$ is the real exchange rate, formally defined as:

$$
\hat{q}_{\mathrm{t}}=\widehat{\varepsilon}_{t}+\widehat{P}_{F, t}-\widehat{P}_{t}
$$

Where, $\widehat{P}_{F, t}$ denotes the foreign consumer-price index.

Denote the slope of the Phillips equation by $\psi$; for the open-economy expression slope of the aggregate supply, equation is $\psi_{1} \equiv \frac{\kappa n \omega_{p}}{1+\omega_{p} \theta}$.

Let us turn to the case of no labor mobility and no capital mobility. If the domestic economy is not integrated to the international financial market, then there is no possibility of consumption smoothing, and we have that the value of aggregate current spending equals the value of aggregate domestic output:

$$
\hat{P}_{C, t} \hat{C}_{t}=\hat{P}_{Y, t} \hat{Y}_{t} \quad ; \quad \hat{P}_{C, t} \hat{C}_{t}^{\mathrm{N}}=\hat{P}_{Y, t} \hat{Y}_{t}^{\mathrm{N}}
$$

Where $\hat{P}_{C, t}$ is the CPI-based price level, and $\hat{P}_{Y, t}$ is the GDP deflator. In this case, the aggregate supply curve is

$$
\begin{aligned}
\hat{\pi}_{t}= & \kappa \cdot\left[\frac{(\omega \cdot n+\sigma)}{1+\omega \theta} \cdot x_{t}+\frac{\omega \cdot(1-n)}{1+\omega \theta} \cdot\left(\hat{Y}_{t}^{\mathrm{F}}-\hat{Y}_{t}^{\mathrm{N}}\right)+\frac{(1-n)}{n} \cdot \widehat{q}_{t}\right] \\
& +\frac{(1-n)}{n} \cdot\left(\hat{q}_{t}-\hat{q}_{t-1}\right)+\beta \cdot E_{t}\left[\hat{\pi}_{t+1}-\frac{(1-n)}{n}\left(\hat{q}_{t+1}-\widehat{q}_{t}\right)\right] .
\end{aligned}
$$


The Phillips-curve slope is:

$$
\psi 2 \equiv \frac{\kappa(\omega n+\sigma)}{1+\omega \theta}
$$

In the closed economy case the aggregate supply equation (Phillips Curve) reduces to

$$
\hat{\pi}_{t}=\frac{\kappa}{1+\omega \theta} \cdot(\omega+\sigma) \cdot x_{t}+\beta E_{t} \hat{\pi}_{t+1}
$$

In the case of the closed economy, the Phillips Curve slope is:

$$
\psi_{3} \equiv \frac{\kappa(\omega+\sigma)}{1+\omega \theta} \geq \psi 2 \equiv \frac{\kappa(\omega n+\sigma)}{1+\omega \theta} \geq \psi_{1} \equiv \frac{\kappa n \omega_{p}}{1+\omega_{p} \theta}
$$

The Phillips curve is steeper in the closed economy case, compared to the open-trade case with no-labor, no-capital. The latter is steeper than the slope with perfect mobility of labor, capital, and goods.

Furthermore, changes in the foreign price pass through into domestic inflation in the openeconomy case, but these effects are absent in the closed economy case. This observation validates the proposition the globalization in the world of great moderation exert inflation moderating influences.

Badinger, H., (2007). "Globalization, Taylor Rules, and Inflation," mimeo, Wirtschaftsuniversität Wien, Vienna, Austria.

Bean, Charles, (2006). "Globalization and Inflation," Bank of England Quarterly Bulletin Q4, 468-475. 
Bentolila, Dolado and Jimeno (2007) "Does immigration affect the Phillips curve? Some evidence for Spain," European Economic Review Volume 52, Issue 8, November 2008, Pages 1398-1423.

Binyamini, Alon and Assaf Razin, (2008), "Inflation-Output Tradeoffs as Equilibrium Outcomes of Globalization,” Israel Economic Review,6 (1):109-134.

Blanchard, Olivier, (2016). "Currency Wars, Coordination, and Capital Controls". NBER working paper $\mathbf{2 2 3 8 8 .}$

Borio, Claudio and Andrew, Filardo, (2007), "Globalization and Inflation: New Cross-Country Evidence on the Global Determinants of Domestic Inflation," unpublished paper, Bank for International Settlements, Basel, Switzerland (March).

Calvo, Guillermo, (1978). "On the Time Consistency of Optimal Policy in a Monetary Economy,” Econometrica 46, November, pp. 1411-1428.

Calvo, Guillermo (1992), " Are High Interest Rates Effective for Stopping High Inflation? Some Skeptical Notes," The World Bank Economic Review, 6:55-69.

Calvo, Guillermo (2016) "From Chronic Inflation to Chronic Deflation: Focusing on Expectations and Liquidity Disarray Since WWWII," NBER working paper 22535.

Calvo, Guillermo A., and Carlos A. Vegh (2001), "Inflation Stabilization and BOP Crises in Developing Countries," in John Taylor and Michael Woodford (eds.) Handbook of Macroeconomics, Elsevier.

Cerutti, E., Claessens, S., Laeven, L., (2015a). The Use and Effectiveness of Macro prudential Policies: New Evidence. IMF Working Papers 15/61, International Monetary Fund. 1, 2.1

Chen, Nancy, Jean Imbs and Andrew Scott, (2004), "Competition, Globalization and the Decline of Inflation," Journal of International Economics 63 (1), 93-118, 312.

Clarida, Richard, J., (2008), "Reflections on Monetary Policy in the Open Economy", NBER International seminar on Macroeconomics 2008, edited by Jeffrey Frankel and

Clarida, Richard, J., (2008), "Reflections on Monetary Policy in the Open Economy", NBER International seminar on Macroeconomics 2008, edited by Jeffrey Frankel and Richard Clarida.

Fleming, Marcus (1962), "Domestic financial policies under fixed and under floating exchange rates,” IMF Staff Papers 9, Nov., 369-380. Mundell 
Fratzscher, M., Lo Duca, M., and Straub, R., (2013). On the international spillovers of US quantitative easing.

Friedman, Milton, 1971, "Government Revenue from Inflation," Journal of Political Economy, 79,4 , pp. 846-856.

Gali, Jordi, (2008). Monetary Policy, Inflation, and the Business Cycle: An Introduction to the New Keynesian Framework. Princeton, NJ: Princeton University Press.

Gopinath, Gita (2004), Lending Booms, Sharp Reversals and the Real, Exchange Dynamics, Journal of International Economics, 62 (1), 1.

Karni, Edi, (1983), "Revenue from Inflation,” Yediot Aharonot.

Krugman, Paul, Maurice Obstfeld, And Marc Melitz, (2015), International Economics:Theory and Policy, Tenth Edition, Pearson.

Kydland, Finn, and Edward C. Prescott, 1977. "Rules Rather than Discretion: The Inconsistency of Optimal Plans," Journal of Political Economy, 85, pp. 473-493.

Leiderman, Leonardo. (1999), editor. Inflation and Disinflation in Israel, Bank of Israel.

Loungani, Prakash, and Assaf Razin (2001), "How Beneficial Is Foreign Direct Investment for Developing Countries", Finance and Development, 38(2).

Loungani, Prakash, Assaf Razin and Chi-Wa Yuen, (2001). "Capital Mobility and the OutputInflation Tradeoff," Journal of Development Economics 64, 255-74.

Mankiw, N. Gregory., (2010). The trilemma of international finance. Available at: http://www.nytimes.com/2010/07/11/business/economy/11view.html

Mishkin, Fredric. S., (2007). "Is Financial Globalization Beneficial?," Journal of Money, Credit, and Banking, Volume 39, Issue 2-3 March-April 2007, Pages 259-294

Mishkin, Fredric. S., (2007). Remarks given at the Annual Macro Conference, Federal Reserve Bank of San Francisco, San Francisco, California.

Mundell, Robert A. (1963), "Capital Mobility and Stabilization Policy under Fixed and Flexible Exchange Rates,” Canadian Journal of Economics, 29, pp.475-485.

Razin, Assaf and Efraim Sadka (1993). The economy of modern Israel: Malaise and promise. University of Chicago Press. 
Rey, Helene (2015) “Dilemma Not Trilemma: Global Financial Cycles and Monetary Policy Independence," NBER working paper 21162.

Rogoff, Kenneth, (2003). "Disinflation: An Unsung Benefit of Globalization?", Finance and Development, Volume 40, No. 4 (December), pp. 55-56.

Rogoff, Kenneth, (2004). "Globalization and Global Disinflation," in Federal Reserve Bank of Kansas City, Monetary Policy and Uncertainty: Adapting to a Changing Economy, proceedings of the 2003 Jackson Hole symposium sponsored by the Federal Reserve Bank of Kansas City.

Romer, D., (1993). "Openness and Inflation: Theory and Evidence," Quarterly Journal of Economics, CVII (4), November, pp. 869-904.

Romer, David, (1998). "A New Assessment of Openness and Inflation: Reply," Quarterly

Sargent, Thomas. J., (1999). The conquest of American inflation. Princeton University Press.

Schneider, Martin, and Aaron Tornell (2004), "Balance Sheet Effects, Bailout Guarantees

Tetlow R. and B. Ironside, (2007). "Real-Time Model Uncertainty in the United States: The Fed, 1996-2003," Journal of Money, Credit and Banking, Vol. 39, No. 7 (October), pp. 1533-1561.

Wynne, Mark, A., and Erasmus K. Kersting, (2007). Openness and inflation. Federal Reserve Bank of Dallas, Staff Paper No. 2. Zhang, Yu. 2011. Essays on banking. Ph.D.

Wynne, Mark, A., and Erasmus K. Kersting, (2007). Openness and inflation. Federal Reserve Bank of Dallas, Staff Paper No. 2. Zhang, Yu. 2011. Essays on banking. Ph.D. 